\title{
Three centuries of shifting hydroclimatic regimes across the Mongolian Breadbasket
}

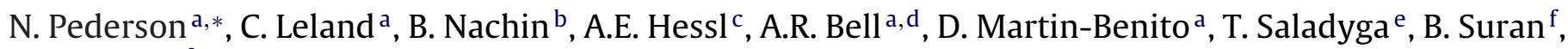 \\ P.M. Brown ${ }^{\text {f }}$ N.K. Davi ${ }^{\mathrm{a}}$ \\ a Tree Ring Laboratory of Lamont-Doherty Earth Observatory and Columbia University, Palisades, NY, United States \\ ${ }^{\mathrm{b}}$ National University of Mongolia, Ulaanbaatar, Mongolia \\ c West Virginia University, Morgantown, WV, United States \\ d International Food Policy Research Institute, Washington, DC, United States \\ e Concord University, Athens, WV, United States \\ ${ }^{\mathrm{f}}$ Colorado State University, Fort Collins, CO, United States
}

\section{A R T I C L E I N F O}

\section{Article history:}

Received 15 May 2012

Received in revised form 28 June 2012

Accepted 3 July 2012

\section{Keywords:}

Mongolia

Tree rings

Regime shifts

Agriculture

Climate variability

Water resources

\begin{abstract}
A B S T R A C T
In its continuing move toward resource independence, Mongolia has recently entered a new agricultural era. Large crop fields and center-pivot irrigation have been established in the last 10 years across Mongolia's "Breadbasket”: the Bulgan, Selenge and Tov aimags of northcentral Mongolia. Since meteorological records are typically short and spatially diffuse, little is known about the frequency and scale of past droughts in this region. We use six chronologies from the eastern portion of the breadbasket region to reconstruct streamflow of the Yeruu River. These chronologies accounted for $60.8 \%$ of May-September streamflow from 1959 to 1987 and $74.1 \%$ from 1988 to 2001. All split, calibration-verification statistics were positive, indicating significant model reconstruction. Reconstructed Yeruu River streamflow indicates the 20th century to be wetter than the two prior centuries. When comparing the new reconstruction to an earlier reconstruction of Selenge River streamflow, representing the western portion of the breadbasket region, both records document more pluvial events of greater intensity during 20th century versus prior centuries and indicate that the recent decade of drought that lead to greater aridity across the landscape is not unusual in the context of the last 300 years. Most interestingly, variability analyses indicate that the larger river basin in the western breadbasket (the Selenge basin) experiences greater swings in hydroclimate at multi-decadal to centennial time scales while the smaller basin in the eastern portion of the breadbasket (the Yeruu basin) is more stable. From this comparison, there would be less risk in agricultural productivity in the eastern breadbasket region, although the western breadbasket region can potentially be enormously productive for decades at a time before becoming quite dry for an equally long period of time. These results indicate that farmers and water managers need to prepare for both pluvial conditions like those in the late-1700s, and drier conditions like those during the early and mid-1800s. Recent studies have indicated that cultures with plentiful resources are more vulnerable when these resources become diminished. Thus, the instrumental records of the 20th century should not be used as a model of moisture availability. Most importantly, the geographic mismatch between precipitation, infrastructure, and water demand could turn out to be particularly acute for countries like Mongolia, especially as these patterns can switch in space through time.
\end{abstract}

(c) 2012 Elsevier B.V. All rights reserved.

\section{Introduction}

Climate change will have a significant impact on agricultural and ecological systems. In fact, warming has already had a significant impact on productivity and prices for important crops like maize and wheat over recent decades (Piao et al., 2010; Dronin and

\footnotetext{
* Corresponding author.

E-mail address: adk@ldeo.columbia.edu (N. Pederson).
}

Kirilenko, 2010; Lobell et al., 2011; Urban et al., 2012; Diffenbaugh et al., 2012). It is not entirely clear how these systems will respond to future climate change, or how these responses will vary spatially. Although it was initially thought that climate change would benefit agricultural production in high latitude regions (Dronin and Kirilenko, 2010), productivity has not necessarily improved due to climatic change over the last 60 years. One striking example is the 2010 heat wave in Russia where the unusual heat exacerbated drought and triggered a significant drop in grain production in some regions (Grumm, 2011; Wegren, 2011). Similarly, higher 
temperatures exacerbated drought conditions, which triggered tree mortality and an ecotonal shift in a forested ecosystem in the southwestern U.S. (Breshears et al., 2005), a pattern seen in other forested ecosystems globally (Allen et al., 2010). Understanding the interaction between climate change and agricultural and ecological systems is vital to ensure resource security.

In its continuing move toward resource independence, Mongolia recently began a new and concerted effort to develop its agricultural resources, Tselina_3 (Regdel et al., 2012). Traditionally, nomadic pastoralism, coupled with agriculture during times of above average rainfall, has been a common land-use strategy in Mongolia (Lattimore, 1938; Humphrey and Sneath, 1999; Fernández-Giménez, 2000), as is typical in other regions that experience tremendous spatial and temporal variability in water resources (Batisani and Yarnal, 2010; Mary and Majule, 2009; Fiebig-Wittmaack et al., 2011). Recent factors have triggered increased concern over food security in Mongolia including: (1) increasing human population (National Statistics Office of Mongolia, 2012), (2) increases in water-demanding activities, including mining (Priess et al., 2011), (3) growing herd populations and alteration of nomadic migration patterns that have led to intensive usage and subsequent degradation of pastures (e.g. Enkh-Amgalan et al., 2012; Regdel et al., 2012), and (4) general vulnerability to climate change (Gregory et al., 2005; Batima et al., 2005). This increase in concern over food security has been especially true for nations in central Asia, like Mongolia, that were directly impacted by the fall of the Soviet Union (Lioubimtseva and Henebry, 2009). According to a study by Rockstrom et al. (2007), 20-35\% of the Mongolian population was undernourished from 2001 to 2002 following a severe drought, a condition that is not uncommon in semi-arid regions with highly variable rainfall. As a result of these concerns, government spending in the food and agricultural sectors of Mongolia increased significantly between 2005 and 2009 (FAO, 2011). The Tselina_3 program, otherwise known as the Third Campaign of Reclaiming Virgin Lands, was an attempt to further stimulate domestic agriculture for increased self-sufficiency and the prevention of future food crises (Bayar, 2008). Of the 156.4 million hectares of Mongolian territory, currently 617.1 thousand hectares are sown for agriculture (Regdel et al., 2012), and large crop fields and center-pivot irrigation are being established across Mongolia's "Breadbasket": the Bulgan, Selenge, and Tov aimags of northcentral Mongolia (Fig. 1a and b).

Instrumental records indicate that Mongolia has generally warmed $1.6^{\circ} \mathrm{C}$ since the mid-20th century and has experienced several severe droughts since the late-1990s (Batima et al., 2005). Climatic trends like these can significantly impact developing, semi-arid nations (Lioubimtseva and Henebry, 2009). In Mongolia, these trends, in combination with severe winters (dzud), have been detrimental to important pastoral productivity (Siurua and Swift, 2002; Angerer et al., 2008). In particular, the droughts seem to be longer and more intense than ever in the collective memories of pastoralists (Marin, 2010). Placing spatial and temporal variability of recent climate change in Mongolia in a historical context is difficult because instrumental data are limited in number, space, and length. The historical extent and severity of droughts in the Mongolian Breadbasket, therefore, cannot be ascertained with instrumental records alone.

Tree-ring data have been used to reconstruct hydroclimatic or drought variability in eastern Mongolia (Pederson et al., 2001; Davi et al., under revision), the Selenge River region in central Mongolia (Davi et al., 2006), far western Mongolia (Davi et al., 2009), and across Mongolia as a whole (Davi et al., 2010). However, none of these studies have fully captured climatic variability specifically in northern Mongolia because until recently, only one droughtsensitive tree ring record existed within much of the Mongolian Breadbasket region (see map, Fig. 1 in Davi et al., 2010). Further, no annually resolved long-term paleohydroclimatic studies have been conducted in southern Siberia, immediately north of our study region (though see Voropay et al., 2011 for a contemporary review and Orkhonselenge et al., 2012 for a recent sediment core investigation). Due to high spatial variability in hydroclimate across Mongolia, as evidenced by instrumental records (Batima et al., 2005) and the aforementioned tree-ring based reconstructions, it is important to sufficiently describe this variability from a historical perspective. Quantifying long-term drought variation in the Mongolian Breadbasket will further our understanding of how historical and recent hydroclimatic patterns might differ relative to previously studied regions in Mongolia.

We collected five chronologies in northern Mongolia from sites that appeared to contain drought-sensitive trees since 2009 (Fig. 1c and d). A spatiotemporal analysis of 20 hydrometeorological records across central and eastern Mongolia, including these new records, indicates that the breadbasket region is climatically distinct from neighboring regions (Leland, 2011; Leland et al., in review). Here we build from this work to create the first hydroclimatic reconstruction in northern Mongolia. Not only is this region important agriculturally, it represents the transition from the southern boreal forest as it grades into taiga of northern Mongolia and southern Russia. Recent changes in hydroclimate might have important impacts on the ecology of the ecosystems in this region (e.g. Dulamsuren et al., 2010, 2011).

\section{Methods}

\subsection{Tree-ring data}

We collected tree-ring samples from five sites in northern Mongolia, a region that was a gap in the pre-existing, MongolianAmerican Tree Ring Project network (Fig. 2, Table 1). Of the six tree-ring sites used in this study, only data from Undur Ulaan were collected in 2002 and used in previous studies (Davi et al., 2006, 2010). Tree-ring data from the other five sites were collected in summer 2009 and 2010. Some sites exhibited obvious dry conditions, with steep slopes, well-drained soils, and open-canopied trees (e.g. DKN and SMN; Fig. 1c and d) while others were heavily vegetated with closed-canopy conditions (e.g. BG, SJD). We targeted trees with classic old-growth morphology for coniferous trees (i.e. loss of apical dominance, spike tops, smooth bark pattern, and low stem taper; Swetnam and Brown, 1992; Huckaby et al., 2003) and extracted two cores per tree, when possible, with a $5.15 \mathrm{~mm}$ diameter increment borer. All cores were processed using standard techniques (Stokes and Smiley, 1968), beginning with fine sanding and visual crossdating of cores. We measured the annual growth rings on each core to a precision of $0.001 \mathrm{~mm}$, and all dating underwent quality control with the program COFECHA (Holmes, 1983).

In order to produce a chronology for each site, individual treering series were standardized using the program ARSTAN (Cook, 1985; Cook and Krusic, 2011). A data-adaptive power transformation was applied to each series in order to stabilize variance through time (Cook et al., 1992; Cook and Peters, 1997). Where necessary, a double detrending procedure was used to account for: (1) allometric growth trends and (2) abrupt pulses in growth likely associated with stand dynamics. The latter were more prevalent in sites with closed-canopy conditions and tree-to-tree competition (Cook, 1985; Cook and Peters, 1981). To remove the effect of allometric growth trends, we applied a linear or negative exponential curve to each series. In the few cases where time-series of radial growth provided visual evidence of changes in tree-level competition (Lorimer and Frelich, 1989) or abrupt reductions in growth like ice storm damage (Lafon and Speer, 2002), a second detrending was conducted with the Friedman Super Smoother 

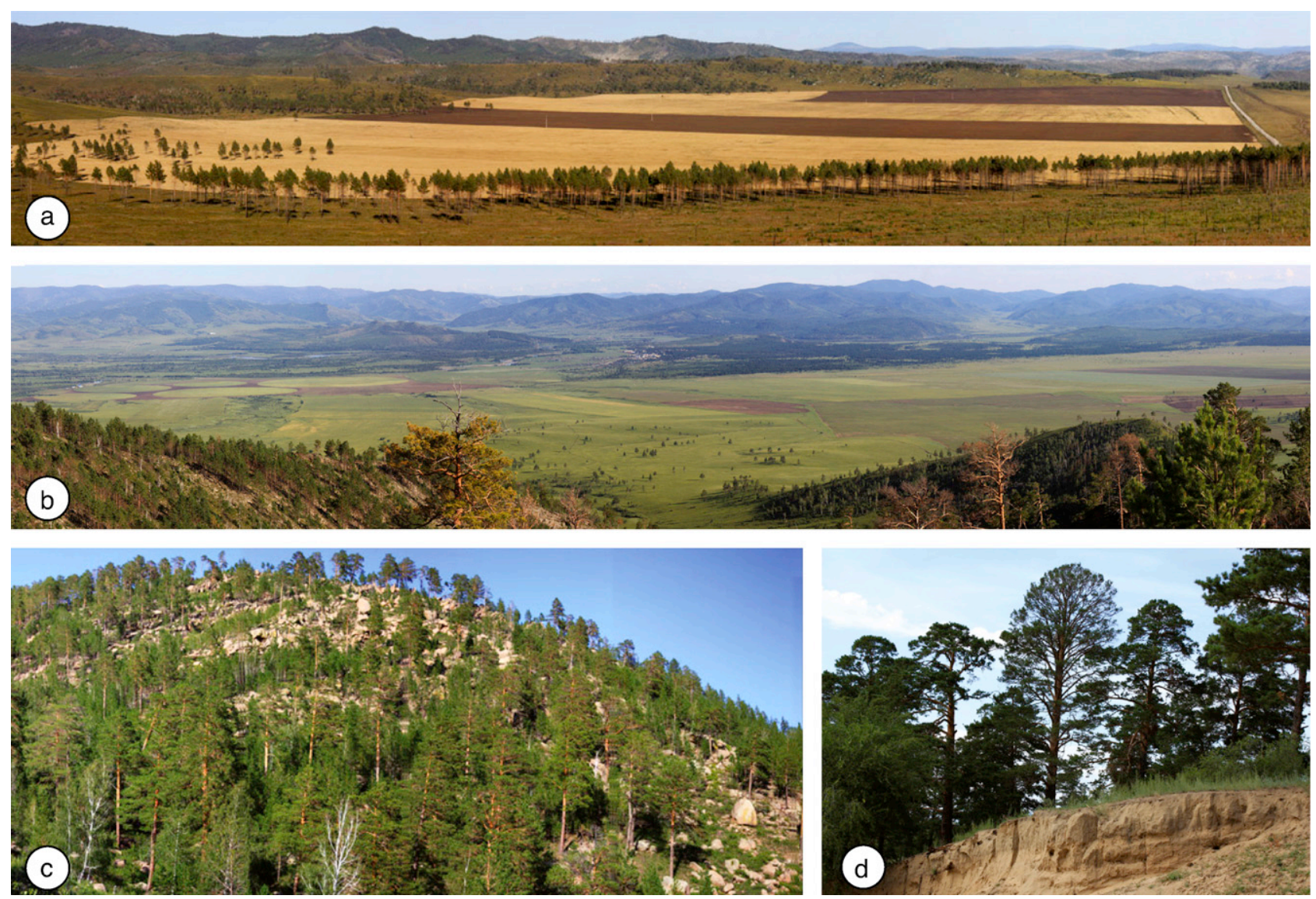

Fig. 1. Scenes of agriculture and forest in the Mongolian Breadbasket region. (a) A valley full of fields in the northwestern Khan Khentii Mountains in August 2010. These fields were not present in 2009. (b) Agricultural fields, including center-pivot irrigation (middle of the scene on the far left), in the northern Selenge River Valley in August 2011. Fields are seen throughout the right side of the scene. The Selenge River can be seen just beyond the center-pivot irrigation fields. (c) Scots pine at Dulaan Khan growing on a shallow-soil, south to southwest facing caldera in northern Mongolia. (d) Scots pine growing on deep sands above the Orkhon River at Shaamar Monhan.

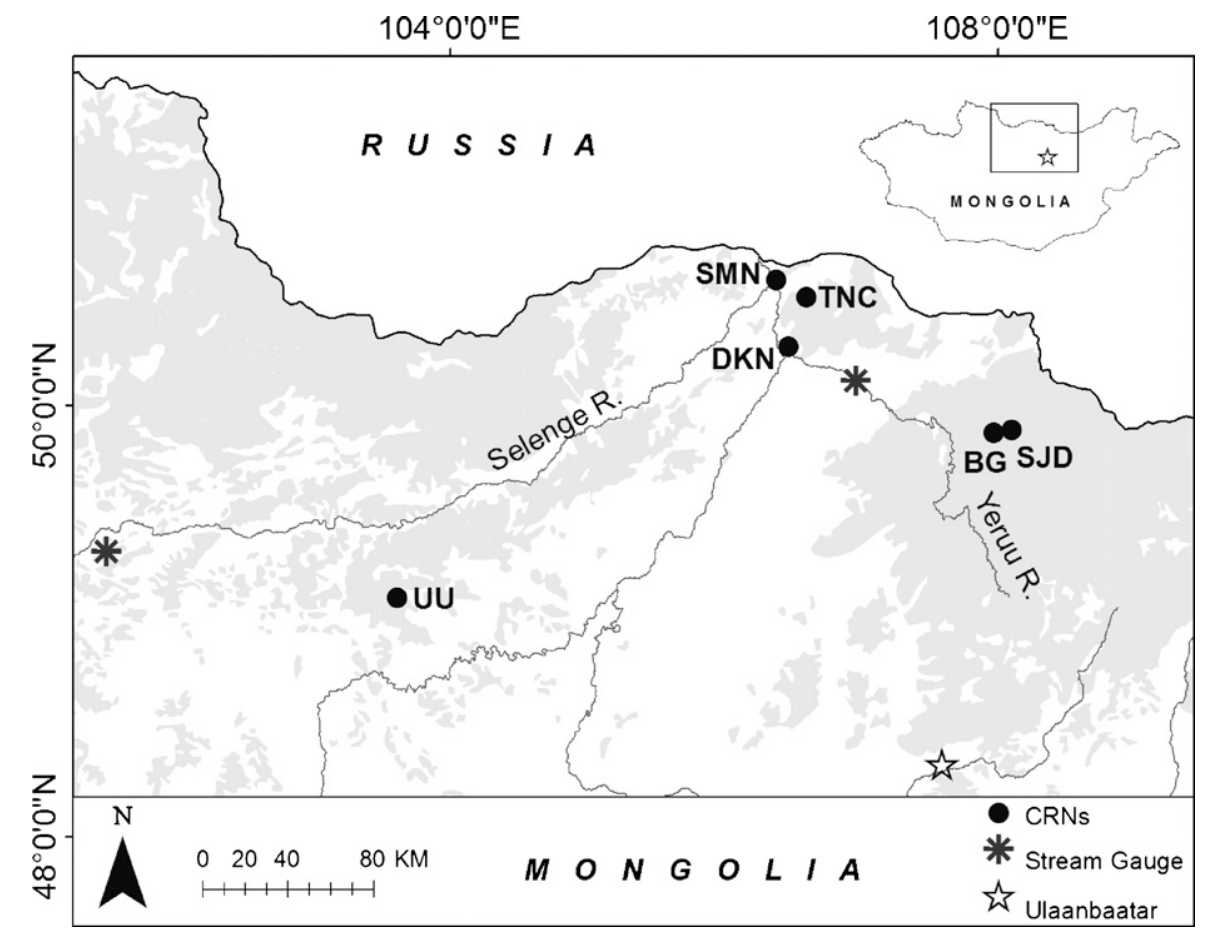

Fig. 2. Map of tree-ring sites and streamflow gauge used in this study. The gauge for the Selenge streamflow reconstruction (Davi et al., 2009) is also shown. 
Table 1

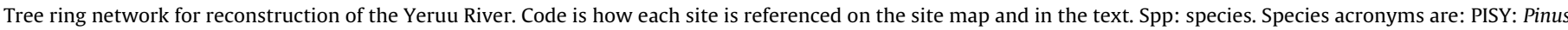
sylvestris; LASI: Larix sibirica. CRN: chronology.

\begin{tabular}{|c|c|c|c|c|c|c|c|}
\hline Site & Code & Spp & No. Ser. & CRN span & EPS (tree) $)^{\mathrm{a}}$ & $\mathrm{EPS}>0.85^{\mathrm{b}}$ & Yr EPS $>0.85^{\circ}$ \\
\hline Bugant & BG & PISY & 34 & 1730-2008 & 0.970 & 1815 & 1793 \\
\hline Dulaankhaan Nars & DKN & PISY & 44 & $1653-2008$ & 0.981 & 1675 & - \\
\hline Shaamar Manhan Nars & SMN & PISY & 17 & 1770-2008 & 0.965 & - & 1786 \\
\hline Shoorgobjyin Davaa & SJD & PISY & 32 & 1626-2008 & 0.919 & 1730 & - \\
\hline Tujyin Nars & TN & PISY & 20 & $1731-2008$ & 0.897 & 1815 & - \\
\hline Undur Ulaan & UU & LASI & 25 & 1510-2002 & 0.978 & 1570 & - \\
\hline
\end{tabular}

a Between tree EPS.

b 50 -Year segment (overlapping 25 years) where between-tree EPS $>0.85$.

c Individual year when between-tree EPS > 0.85 if earlier than 'b'.

(Friedman, 1984) to reduce the effect of competition or disturbance-driven changes in growth (Supplemental Fig. s1). For the collections used in for the Yeruu reconstruction, this was conducted on nine of 27 series at Undur Ulaan to all 18 series at Tujyin Nars with $53-87 \%$ of the series in the remaining collections detrended a second time. This type of detrending ultimately causes a tradeoff that results in the loss of some low frequency climatic information in an exchange for a reduction of non-climatic changes in ring width.

A robust mean chronology was produced using the standardized series for each site in the program ARSTAN, and the variance was stabilized for each chronology to take into consideration changes in the number of series through time (Frank et al., 2006). We used standard chronologies for classic drought sites and ARSTAN chronologies for sites with prevalent changes in tree-to-tree competition. This decision was based on whether the forest sampled was a closed-canopy forest (i.e. the crowns of neighboring trees were touching or closely spaced). The ARSTAN chronology pools the common autoregressive properties of the individual series and places it back into the prewhitened chronology making it is more suitable for sites with clear endogenous disturbances (Cook, 1985). All chronologies were truncated when the between-tree expressed population signal (EPS) statistic dropped below 0.85 (Wigley et al., 1984), suggesting that the common signal among series was diminished. In order to extend the common period of all chronologies, we used the Bugant and Tujyin Nars chronologies back to 1800, despite their drop below an EPS of 0.85 around 1815 .

\subsection{Streamflow data}

Yeruu River monthly streamflow data was collected from a gauge in the town of Yeruu, Mongolia for the period 1959-2009 (Fig. 2). The watershed area for the Yeruu River at this gauge is roughly $8975 \mathrm{~km}^{2}$ (Stubblefield et al., 2005). The hydrograph suggests that Yeruu streamflow is particularly seasonal, with the majority of flow occurring from May through October, with noticeable peak flows from June to August (Supplemental Fig. s2a). Because of this distribution of flow and the general hydroclimatic sensitivity of the new network (below), we decided to reconstruct streamflow for a 5-month window of May through September.

\subsection{Reconstruction}

The Yeruu streamflow reconstruction was produced using a principal component regression (PCR) program that employs maximum entropy bootstrapping to derive confidence intervals around reconstructed values (Ahmed and Cook, 2011). The calibration period for this analysis was 1959-1987 (29 years), with 1988-2001 (14 years) being withheld as the verification period. Six chronologies were included as potential predictors for May-September average Yeruu streamflow for $t$ and $t+1$ (a total of 12 predictors) and were tested for significant, positive correlation
(95\% significance screening; positive 1-tail) with the streamflow data during the calibration period. The chronologies with a positive association to May-September streamflow were entered into a principal components regression for reconstruction. Despite previously being used in the Selenge River reconstruction (Davi et al., 2006), Undur Ulaan was included in the Yeruu reconstruction, because: (1) a rotated principal component analysis from 1790 to 1994 of 20 series across central Mongolia indicates that Undur Ulaan loads nearly as strongly in the Yeruu River reconstruction region as the Selenge River reconstruction region (northern versus western region in Leland et al., in review); loads at 0.37 versus 0.51 , respectively, (2) Undur Ulaan is significantly and strongly correlated to Yeruu River streamflow (Fig. 3), and (3) it boosts replication prior to 1790 .

The initial reconstruction produced seven negative streamflow values between 1680 and 1955 . As a result, we investigated the relation between the instrumental versus the reconstructed values between 1959 and 2001 (see Section 3 to see why 2001 was the last year of the reconstruction). We found that the 1973 instrumental value caused a lever in the relation between measured and reconstructed streamflow (Supplemental Fig. s3). When comparing the Yeruu instrumental streamflow record versus the nearby instrumental record for the Selenge River, we see that while 1973 was an above average year, it was not an outlier as in the Yeruu instrumental data (Supplemental Fig. s4). Because of this, we replaced the 1973 monthly values from May to September with the average of the remaining years and proceeded with our final reconstruction.

The reconstructed values reported here represent median values from pseudo-reconstructions created by the maximum entropy

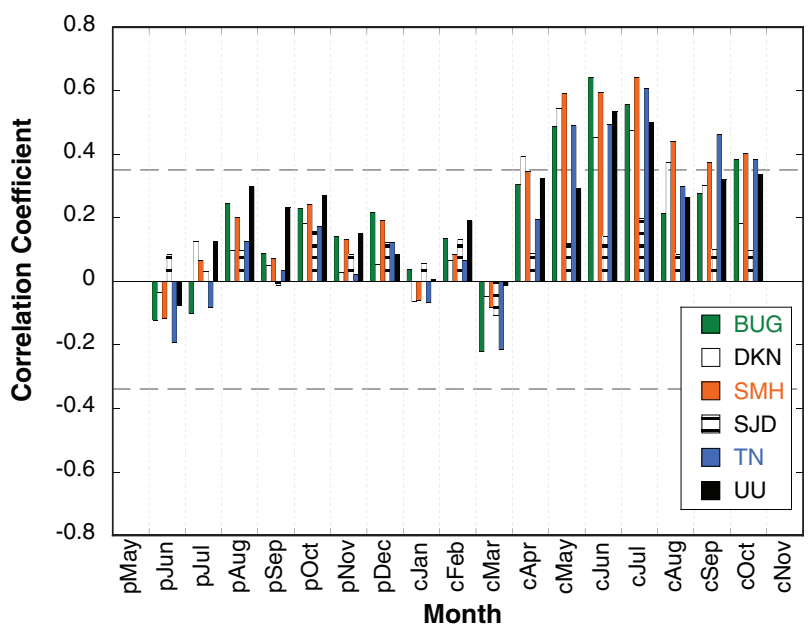

Fig. 3. Correlation to measured Yeruu River streamflow from prior May through current October. Chronology abbreviations are: BG: Bugant; SJD: Shorgooljyin Davaa; SMH: Shaamar Manhan; TNC: Tujyin Nars; DKN: Dulaan Khan Nars; UU: Undur Ulaan. The gray, horizontal dashed line represents $p \leq 0.05$. 

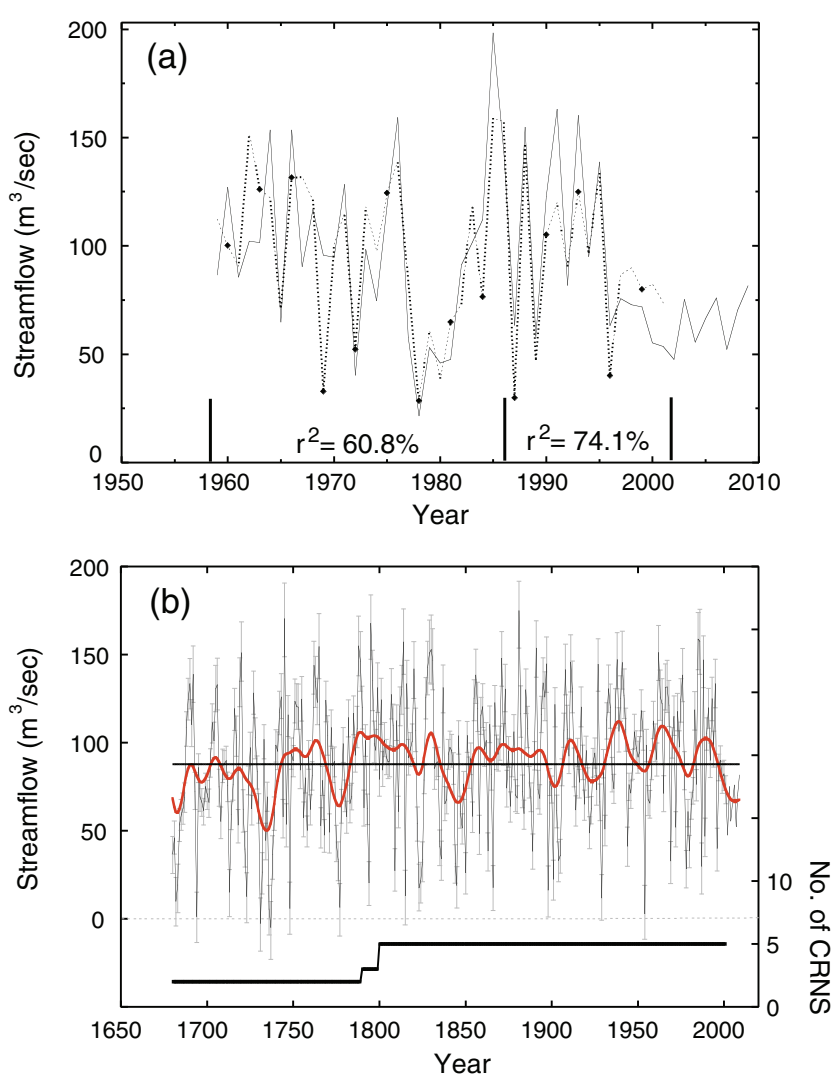

Fig. 4. Yeruu River streamflow. (a) Measured May-September streamflow (solid line; 1959-2009) versus reconstructed May-September streamflow (dashed line; 1959-2001). Tree rings account for $52.8 \%$ of the annual variance from 1959 to 1987 and verified at $r^{2}$ of $54.2 \%$ from 1988 to 2001. Note: the instrumental streamflow data does not contain the original outlier value for 1973 . To see that data point, see supplemental material. (b) Reconstructed May-September streamflow from 1680 to 2001 (solid line) with annual 95\% maximum entropy bootstrap confidence limits (gray bars). The smoothed curve, a 20 -year spline, emphasizes decadal-scale streamflow variation while the thin, solid black line represents the long-term mean. The gray, dashed horizontal line represents zero flow. The lower, solid, think black line represents chronology replication. There are two chronologies present in the reconstruction from 1680 to 1789.

bootstrapping of predictor and predictand data (Vinod, 2006; Ahmed and Cook, 2011). The bootstrapping procedure provides confidence levels at the 5th and 95th quantiles of the pseudoreconstructions. A nested procedure was used in the streamflow reconstruction where younger chronologies were dropped as predictors going backwards in time (e.g. Meko, 1997; Cook et al., 2003). There were four total nested regression models that passed verification tests: 1800-2001 (full nest); 1790-2001; 1680-2001; 1593-2001. However, we chose to not include the last nest (1593-2001) because it was based upon only one chronology (Undur Ulaan), and therefore not likely to fully reflect hydroclimatic variability in the breadbasket region. The nests were scaled to account for changes in variance and the older sections of each nest were stitched together to create the final reconstruction.

\subsection{Analysis}

To investigate the entire Mongolian Breadbasket region, we compare the Yeruu River reconstruction produced here to the Selenge River reconstruction established by Davi et al. (2006) (available here: ftp://ftp.ncdc.noaa.gov/pub/data/paleo/treering/ reconstructions/mongolia/selenge-riverflow.txt). We will not elaborate on methods used for the Selenge reconstruction as they are

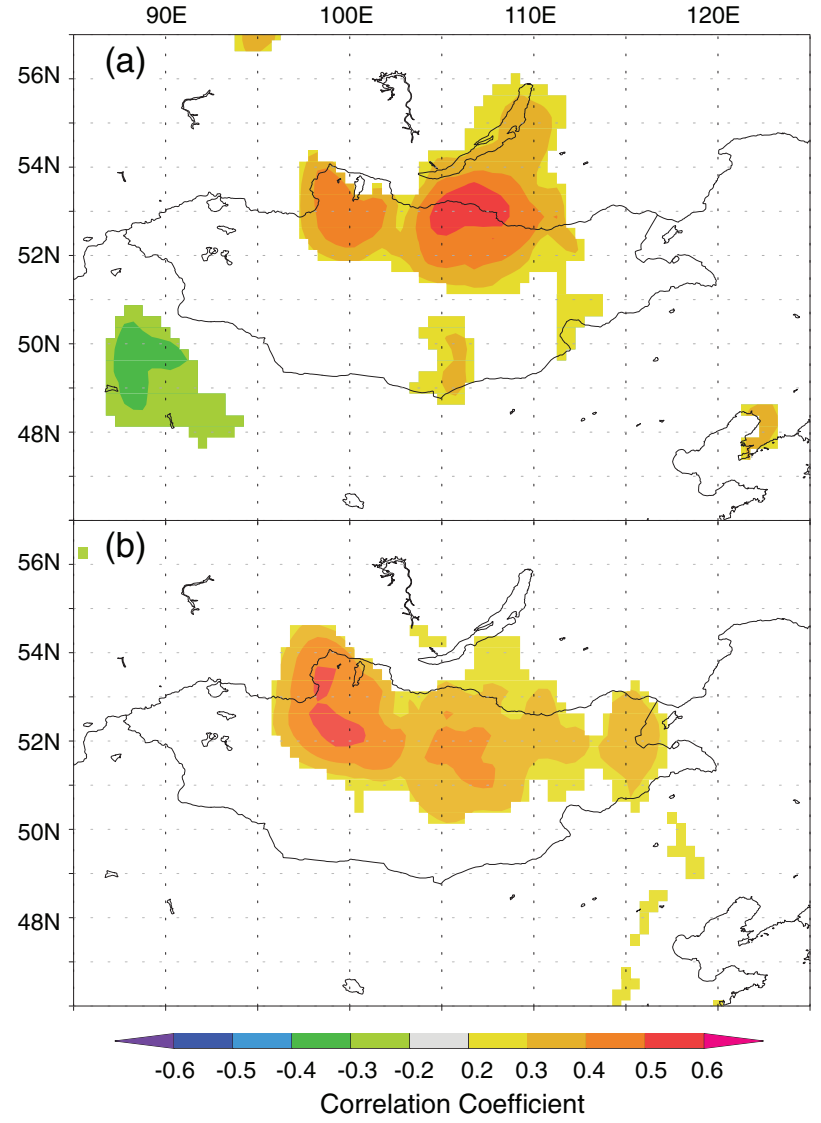

Fig. 5. Spatial correlation map of the Yeruu reconstruction (top) and Selenge reconstruction (bottom) with June-August averaged precipitation from CRU TS3.1 spanning 1950-2001. Meteorological stations in Mongolia are sparse, have missing values are often short in length, and rarely have data before the 1950s. Here, we wanted to work with the longest possible, but most reliable instrumental data.

not too dissimilar to the methods used here. However, we have three things of note regarding the Selenge River reconstruction: first, the Undur Ulaan chronology is shared in common between both reconstructions analyzed here, and second, standardization of the tree ring records used for the Selenge River reconstruction was slightly different than our methods. For the Selenge reconstruction, time-series of ring widths were 'conservatively detrended' to retain low frequency information (Davi et al., 2006). This includes primarily removing geometric declines in raw ring widths using negative exponential or straight-line curve fits. Finally, only standard chronologies were used for reconstruction of the Selenge River.

We performed five analyses on the Selenge and Yeruu reconstructions to investigate hydroclimatic variability across the Mongolian Breadbasket region. First, dry and wet events $(<$ or $>$ the long-term median, respectively) of two years in length and greater were calculated following Gray et al.'s (2011) adaptation of Biondi et al. $(2002,2005)$ and graphed to display the changing magnitude (sum of the departure values from the median) and intensity (sum of the departure values from the median divided by the duration) of these events through time. Second, we used density distribution plots to illustrate the distribution of reconstructed streamflow values for $\sim 50$-year periods. Additional density analyses, for the full length of the reconstructions, and 30-, 75-, and 100 -year periods, were also tested to ensure that the patterns we identified were not an artifact of the 50-year subset we initially selected (see Supplemental Material). Third, we used proportion 
plots to display the time-varying proportion of drought years (i.e. streamflow values $<1$ SD below the mean) and pluvial years (i.e. values $>1$ SD above the mean) for both reconstructions using a moving 50-year window. Differences between density distributions for different periods were tested through Kolmogorov-Smirnov test. Fourth, we applied empirical cumulative density functions (ECDFs) to both reconstructions for droughts and pluvials (as defined above) using methods similar to those prescribed by Meko et al. (2011). The ECDFs were produced using the frequency of drought (pluvial) years for overlapping, 50-year moving windows shifted one year for each streamflow reconstruction (e.g. 1680-1729, 1681-1730, $1682-1731$, etc.). Lastly, we calculated average standard deviations for 50-year moving windows and plotted 1680-2001 for the Yeruu reconstruction and 1675-1997 for the Selenge reconstruction.

\section{Results}

All of the chronologies in our network are positively correlated to Yeruu River streamflow between current April and October (Fig. 3). The strongest positive correlations for most of the records in the northern Mongolian network are found between current year's May-July. Correlations are generally positive during the previous August through December season, but none of the chronologies are significantly correlated to streamflow during the prior year. Only the Shorgooljyin Davaa chronology is not significantly correlated to streamflow and was therefore not used in the subsequent reconstruction.

The new northern Mongolian chronology network accounted for $60.8 \%$ of the annual, May-September streamflow from 1959 to 1987 for the full nest model (1800-2001). This model verified with an $r^{2}=74.1 \%$ from 1988 to 2001 (Fig. 4a). Not surprisingly, none of the potential $t+1$ (prior year) predictors were significant (Fig. 3 ) and were therefore not included in any of the nested models. The full nested (1800-2001) model used all five chronologies as predictors (DKN, SMN, BG, UU, TN); the 1790-1799 nest used DKN, SMN and UU; and the final nest (1680-1789) model was constructed using DKN and UU as predictors. Considering that only two chronologies were used in the oldest nest, our results prior to 1790 should be taken with caution. Split, calibration-verification statistics were positive for all nests going backwards in time (Supplemental Fig. s5), indicating significant model reconstruction skill. The full reconstruction covers May-September streamflow from 1680 to 2001 (Fig. 4b). The mean reconstructed May-September Yeruu River streamflow from 1680 to 2001 is $88.36 \mathrm{~m}^{3} / \mathrm{s}$ (standard deviation of $\pm 37.3 \mathrm{~m}^{3} / \mathrm{s}$ ). A total of two negative streamflow values were reconstructed prior to the instrumental record. Both occur during two separate drought events between 1729 and 1739. None of the upper $95 \%$ maximum entropy bootstrap confidence limits reconstructed are negative. Notable periods of streamflow include generally lower flows from 1680 to 1740 , above average streamflow from the 1780 s to 1830 s and the 1850 s to 1890 s. The 20 th century is characterized by four sizable pluvial events between 1907 and 1996. Drought magnitude and intensity analysis (below) reveals six pluvial events 4-7 years in duration. Further, mean streamflow of the 20th century $\left(1900-1999=92.6 \mathrm{~m}^{3} / \mathrm{s}\right.$, SD of $\left.\pm 34.7 \mathrm{~m}^{3} / \mathrm{s}\right)$ is slightly higher than mean streamflow for the previous centuries $\left(1700-1799=85.2 \mathrm{~m}^{3} / \mathrm{s}\right.$, SD of $\pm 39.2 \mathrm{~m}^{3} / \mathrm{s} ; 1800-1899=91.2 \mathrm{~m}^{3} / \mathrm{s}$, $\mathrm{SD}$ of $\left.\pm 37.2 \mathrm{~m}^{3} / \mathrm{s}\right)$.

The Yeruu River (this study) and the Selenge River reconstructions (Davi et al., 2006) are significantly correlated to gridded $\left(0.5^{\circ}\right.$ resolution) CRU TS 3.1 summer precipitation data (Mitchell and Jones, 2005) over much of northern Mongolia (Fig. 5). While the broad correlation patterns are similar for both reconstructions, the highest correlation for the Yeruu reconstruction is concentrated over the eastern portion of the Mongolian Breadbasket while the Selenge reconstruction is most strongly correlated to the western portion of the Mongolian Breadbasket.

Magnitude and intensity of 2+ year pluvial and droughts events of the reconstructed Yeruu and Selenge River streamflow are compared in Fig. 6. More severe drought events are seen from the late-18th through the mid-19th century in the western breadbasket region (Selenge River basin) versus the eastern breadbasket region (Yeruu River basin). Both records indicate drier periods during the early-19th century and generally wetter periods during the 20th century. The biggest differences between the records are the greater persistence of pluvial and drought events in the Selenge River basin after the 1790s.

Comparison of the Yeruu and Selenge River reconstructions indicate common variation in decadal streamflow between ca 1730 and 1800 and toward the end of the 20th century (Fig. 7) and correlate annually at $0.397, p<0.0001$ ) from 1680 to 1997 (Supplemental Fig. s6). The biggest difference between the two records occurs during the early-1800s, where the Selenge River basin experienced a more severe drought during the first half of the 19th century and a shorter, but more intense drought during the 1850s. Further, running standard deviations suggest that variability was the lowest during the turn of the 19th century for the Selenge River, whereas variability was relatively higher for the Yeruu River (Supplemental Fig. s7). Interestingly, the standard deviations of streamflow values increased for the Selenge River during the mid-1800s, whereas it decreased significantly at that time for the Yeruu River. Similar to the magnitude and intensity plots (Fig. 6), the decadal comparisons of streamflow also show more moist conditions during the 20th century (Fig. 7). The 20th century is characterized by a strong trend of increasing extreme pluvial years and decreasing extreme drought years in the Selenge reconstruction, though the wetting trend in the Yeruu during the most recent century is not as obvious (Supplemental Fig. s9). Additionally, dots in Supplemental Fig. s10, representing the most recent 50 -year period (1948-1997) in both reconstructions, not only highlight the relatively wet conditions of the Selenge region during this time, but also the slightly more average conditions of the Yeruu region.

The Yeruu and Selenge reconstructions have different density structures, reflecting different distributions of streamflow through time (Fig. 8). For the Yeruu reconstruction, all 50-year density plots have a similar distribution, in which no single pair of 50-year periods has a statistically different $(p \leq 0.05)$ distribution (Supplemental Table s1). All 50-year periods in the Yeruu reconstruction share a negative skewness and have a narrow range of kurtosis $(2.23-2.77 ; 1700-1997$ kurtosis $=2.59)$ in the distribution of the streamflow values (Supplemental Table s2). In contrast, the Selenge reconstruction density plots have more variability in skewness (range of -0.34 to 0.86 ) and a broader range of kurtosis $(2.06-3.22 ; 1700-1997$ kurtosis $=2.39)$. Further, the Kolmogorov-Smirnov statistics suggest that eight pairs of 50 -year periods in the Selenge reconstruction are statistically different $(p \leq 00.05)$ (Supplemental Table $s 1)$. Interestingly, the Selenge reconstruction is composed of nearly two different modes, where one state is characterized by persistent low flow below the long-term median (1700-1749, 1800-1849, 1850-1899), while the other state can be characterized as having a broader range of flow above the long-term median (1750-1799, 1900-1949, 1950-1997) (Fig. 8). This pattern, not obvious in the density plot of the entire reconstruction (1700-1997), persists when we analyze 30, 75, and 100-year segments (Supplemental Fig. s8). Likewise, the more unimodal density structure of the Yeruu reconstruction also persists across these various segments of time (Supplemental Fig. s8). 

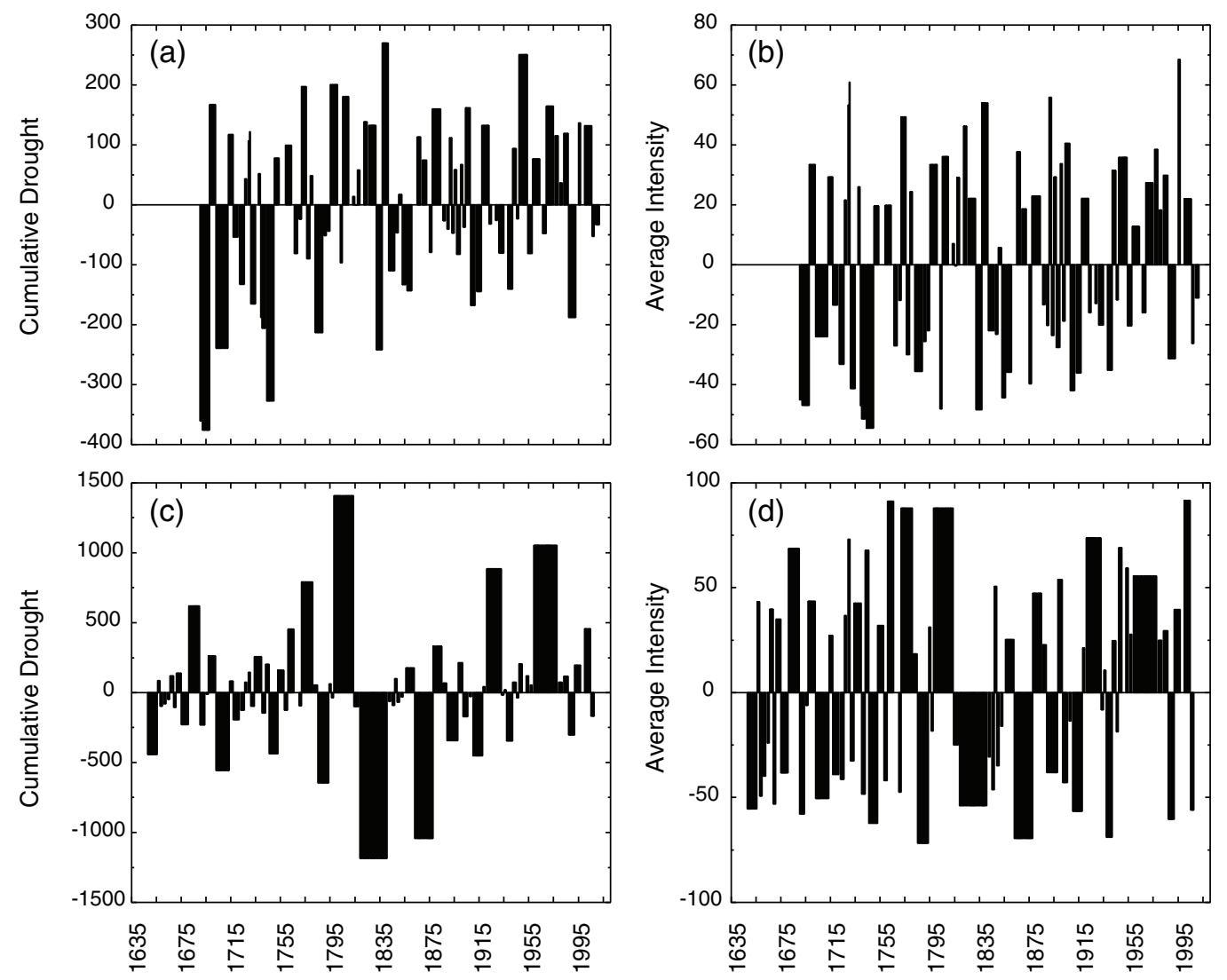

Year

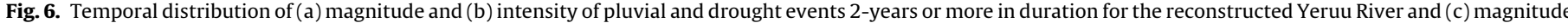

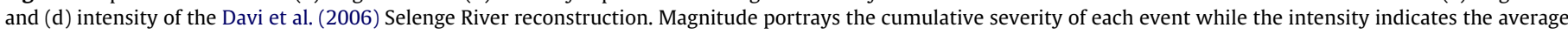
severity of each event. Note: the $y$-axis scales differ.

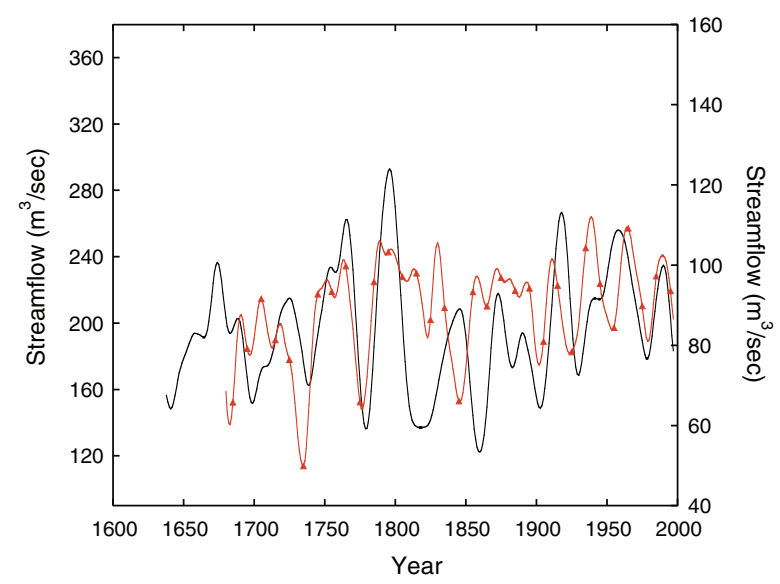

Fig. 7. Comparison of the Yeruu (orange line with triangles) and Selenge River (solid line) reconstructions. Since the mean and standard deviation of each record is different, $y=$ axis scales were set at one-half and twice the mean of each record. Each annual record was smoothed with a 20 -year spline. (For interpretation of the references to color in this figure legend, the reader is referred to the web version of the article.)

\section{Discussion}

By studying the drought history since $1700 \mathrm{CE}$ in the western (Selenge River basin) and eastern (Yeruu River basin) portions of the Mongolian Breadbasket, we find: (1) distinctive spatial and temporal variability in hydroclimate; (2) that, while both records show a wetter 20th century and a reduction of persistent drought events during this interval, the western portion of the breadbasket indicates a more persistent and intense wetting trend (Figs. 5-7, Supplemental Figs. s9 and s10); and (3) most surprisingly, the
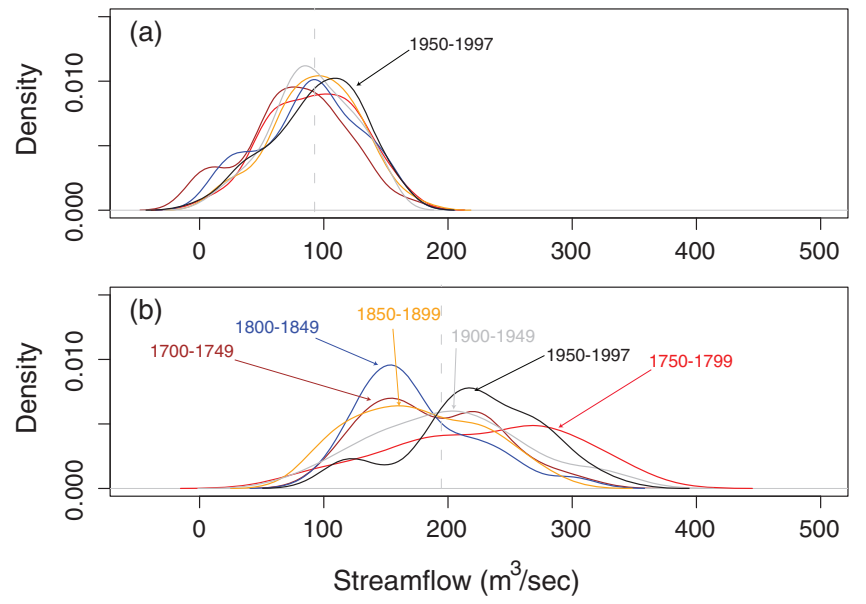

Fig. 8. Probability distributions for 50 -year periods of the (a) Yeruu and (b) Davi et al., 2009 Selenge streamflow from 1700 to 1997 . Each reconstruction was analyzed for the same 50 year intervals, e.g. 1700-1749, 1750-1799, .., 1950-1997. Each period of analysis has a unique line color has its peak labeled. As the Selenge reconstruction has the greater range of density structure, all intervals are labeled in (b) for clarity. The 1950-1997 interval is labeled for the Yeruu (a) to highlight the increased streamflow versus prior intervals. The dashed, vertical line in (a) and (b) represent median streamflow for the entire length of each record. 
Selenge, representing the western portion of the breadbasket and the larger river basin, appears to have a bimodal state that swings between wetter and drier regimes at multi-decadal to centennial scales while the Yeruu, the smaller basin representing the eastern portion of the Mongolian Breadbasket, maintains a more stable or unimodal pattern of hydroclimate (Fig. 8, Supplemental Figs. s8-s10). These contrasting patterns of hydroclimate modality likely have important implications for water resource management efforts in the Mongolian Breadbasket region should these patterns continue into the future.

\subsection{Hydroclimatic history of the Mongolian Breadbasket-1700 to present}

There are important considerations regarding the Yeruu reconstruction. First, we only have two tree-ring records prior to the 1790 nest, so interpretations during this time period should be taken with some caution. However, these two chronologies have EPS values $>0.85$ back to 1675 (Table 1 ). We are also able to compare the Yeruu reconstruction during the 1700 s to a new Kherlen River reconstruction (Davi et al., under revision). The new Kherlen reconstruction has five chronologies throughout the 1700s, including the Dulaan Khan chronology used for the Yeruu reconstruction. The range of variability in the Yeruu is within the range of variability except for a slightly stronger drought centered on 1780 and a greater pluvial during the 1790s in the Yeruu (data not shown). Replication from 1770 to 1799 ranges from 2 to 3 chronologies and 53 to 60 time series for the Yeruu reconstruction, and therefore might not be a critical issue between the Yeruu and Kherlen reconstructions during this period.

Interpretation of the negative values also needs some consideration. First, we only had 29 years for calibration, which is quite short. These years do not likely contain the full range of streamflow variability. Second, the bootstrap confidence intervals for both negative reconstructed values are positive. Thus, the 'actual' reconstructed streamflow values for these years potentially reside on the positive side of flow. Finally, it is not outside the realm of possibility that in extreme years the Yeruu dried or experienced negligible streamflow. Though zero flow during these years is a possibility, it is important to remember that the values here are proxies of streamflow. We do note that as of 2007, a survey estimated that 887 small rivers, 2096 springs, and 1166 small lakes went dry in Mongolia during the most recent drought (Regdel et al., 2012), supporting the idea that the Yeruu could run dry during extreme events. In fact, the recent aridification occurred after a decade of drought, a drought that while severe, is not extraordinary in the context of our new reconstructions of drought in Mongolia (this study; Davi et al., 2010, under revision). We also note that this is not an issue if we were to reconstruct the Palmer Drought Severity Index as PDSI is not constrained to exclusively positive values like streamflow, which can lead to inconsistencies when linear models are used. We chose to reconstruct streamflow as it is a measurable value that is directly relevant to irrigation agriculture and water resource management. Finally, these two negative values do not compromise the major findings of the study, including differences in hydroclimatic persistence between the eastern and western portions of the Mongolian Breadbasket or alter the repeated and intense pluvial events of the 20th century.

Please see Davi et al. (2006) for a detailed overview of the Selenge River reconstruction. Briefly, our new analysis indicates that the Selenge instrumental record has a similar, albeit slightly broader distribution of values, with higher mean monthly flow, compared to the Yeruu (Supplemental Fig. 2b). Most important are the intense and extended hydroclimatic events present in the Selenge reconstruction over the last 300 years (Figs. 6c, d, and 7). The Selenge experienced high streamflow around the turn of the 19th century and then experienced two severe droughts during the first half of the 19th century. Since that time, the western breadbasket region has experienced a long-term increase in streamflow that is more similar to hydroclimatic trends of farwestern Mongolia (Davi et al., 2009) than eastern Mongolia (Davi et al., under revision). It could be that this western breadbasket region is an important hinge of hydroclimatic variability between eastern and western Mongolia.

\subsection{The 20th century pluvial}

Both reconstructions indicate that the 20th century was unusually wet, with above-average streamflow after ca 1940. Generally, the 20th century is characterized by a reduction of persistent drought events during this interval (Figs. 5-7, Supplemental Figs. s9 and s10). While both records end just prior to the severe droughts beginning in the late-1990s, this pluvial trend of the 20th century has clearly not continued into the 21st century according to instrumental records (Supplemental Fig. s4). The eastern portion of the Mongolian Breadbasket had three prominent pluvial events of roughly a decade in length centered on ca 1938, 1964, and 1989 and a smaller and shorter pluvial centered on 1911 (Figs. 4b, 6a, b, and 7). The western portion of the breadbasket indicates a more persistent and intense wetting trend over the 20th century characterized by intense and extended pluvials centered on ca 1917, 1958, and 1988 (Figs. 6c, d, and 7). No other 100-year period matches the amount of years of above-average streamflow of the 20th century. Only the $1750-1850$ period is similar in the eastern breadbasket region. While the current, decade-long drought is a severe shift from the prior 100 years of moist hydroclimate, it does not appear to be unusual compared to 1600-1750. From this record it is apparent that farmers and water managers need to prepare for both pluvial conditions, like those since the early-1900s, and highly variable, but drier conditions like those in previous centuries. Recent studies have indicated that cultures with plentiful resources are more vulnerable when these resources become diminished (Dahlin, 2002; Lucero, 2002; Hornbeck and Keskin, 2011). The relatively higher moisture availability since the early-1900s could have also moved ecosystems in this region to a different state versus historic eras; there is some oral history suggesting that there was less forest in the northern portion of our study area in the past than what exists currently (Anonymous Hyagalant Villagers, personal communication). If true, and if the current drought signals a return to drier conditions, it might be that this region of northern Mongolia will revert to a less forested landscape. Worse, if future drying is accompanied by expected warming, then a dieback of the forest could be dramatic. Such a change is significant as only $\sim 8.1 \%$ of Mongolia is forested (Dugarjav, 2006). Land management strategies based on 20th century hydroclimate are likely to be challenged by droughts like those of the early 21 st century.

\subsection{The western breadbasket pendulum of hydroclimate}

Perhaps the most surprising aspect of our results is that the larger river basin, in the western region, the Selenge River, appears to have more abrupt shifts in climate than the smaller basin in the eastern region, the Yeruu River basin. We had some concerns that differences in standardization methods between the two reconstructions could have caused these patterns. In particular, we were curious if the standardization methods used in this study could reduce the amount of low-frequency variability in the Yeruu River reconstruction. In tree-ring series from heavily cut forests, there is generally a lack of low-frequency variation in final chronologies (Pederson et al., under revision). Therefore, we conducted a few experiments (see Supplemental Fig. s8, for example), including restandardizing the tree ring records using different methods and 
using different reconstruction methods (results not shown). Specifically, we re-standardized all chronologies used for the Yeruu River reconstruction using the more conservative methods described in Davi et al. (2006). We see less low frequency variability in the final Yeruu reconstruction versus a more conservative standardization, however, the unimodality of Yeruu reconstruction remains mostly consistent in both versions of the reconstruction. Conversely, we re-created the Selenge reconstruction using the newer standardization and reconstruction methods detailed in this study. In this case, the Selenge reconstruction still displays a more obvious pattern of bimodality relative to the Yeruu reconstruction. Not wanting to increase the length of the results here by introducing a new Selenge River reconstruction and seeing no evidence that the general pattern reported here changed with these tests, we decided to simply re-use the Davi et al. (2006) reconstruction for our analysis. As a result, our testing indicates that contrasting modality features of the two constructions are not solely an artifact of methodology.

Through all of these tests, the western breadbasket region has more of a bimodal distribution of streamflow through time that can be characterized by swinging between persistent wet and dry regimes at multi-decadal to centennial scales (Figs. 6 and 8, Supplemental Figs. s8-s10). In comparison, streamflow in the eastern breadbasket region has fewer persistent extremes through time. For example, the western breadbasket region was extremely dry during the 1700-1749 period, shifted to a much wetter period from 1750 to 1799 , reverted back to below average streamflow during the 19th century, and then evolved to a wetter 20th century. Conversely, the eastern breadbasket region does not have marked changes in extreme, persistent, hydroclimatic events (Fig. 8). We expected to see more bimodality when calculating probability density functions for 30 -years segments. Results show no modality in the east like the western portion of the breadbasket (Supplemental Fig. s8). Therefore, as the eastern and western breadbasket regions appear to be somewhat climatically distinct (Figs. 5-7, Supplemental Figs. s8-s10; Leland, 2011), we can conclude here that over the last three centuries the western breadbasket region is less stable hydroclimatically and could be more risky in terms of agricultural production versus the eastern breadbasket region if the same patterns of climatic variability hold in the future.

This result is highly surprising given that we would expect more flashiness or higher hydroclimatic instability in the smaller system (Yeruu). This finding suggests that the western breadbasket region is a highly sensitive region to climatic change. It is beyond the scope of this paper to determine the complex mechanisms behind precipitation variation and climatic forcing in central Mongolia, especially given that multiple different climatic systems are likely interacting and influencing hydroclimatic variability (see: Sato et al., 2004, 2007; Davi et al., 2010; Ummenhofer et al., accepted). However, we will offer a few hypotheses for pursuit. One possible factor for the 'stability' of the Yeruu versus the Selenge is that the Yeruu's streamflow gauge is closer to the snowpack in its headwaters of the Khentii Uul. The climatology of regional precipitation, however, shows that very little precipitation falls in the winter. While precipitation increases with altitude, our comparison of reconstructed streamflow to snowpack data on KNMI Climate Explorer (http://climexp.knmi.nl/start.cgi?id=someone@somewhere)

shows no relation between the two variables (data not shown). Second, the vegetation type in the Yeruu watershed versus the Selenge watershed could influence regional climatology (Sato et al., 2004). Vegetation of the Selenge is mostly forest-steppe while some of the vegetation of the Yeruu is alpine taiga. Sato et al. (2007) postulated that, while topography is likely a more important factor in determining cloud frequency, the vegetation type could influence cloud formation, which would in turn influence the convective nature of the precipitation regime in this part of Mongolia. Therefore, we would put forth the idea that the geographic orientation of the Khentii Uul (from northeast to southwest) on the eastern edge of the Yeruu watershed, the prevailing winds (flowing from northwest to southeast), and proximity of the Yeruu watershed in the Khentii Uul to Lake Baikal, might provide a more constant source of moisture versus the Selenge basin. The Selenge basin is characterized with a northwest to southeast orientation of the Khangai Uul at the basin's southern margin, a lack of mountains at the eastern end of the basin, and greater distance to substantial bodies of water (Lakes Baikal and Hovsgol). It would seem that the geographic location and configuration of the Yeruu basin and prevailing storm track could provide the Yeruu with a more regular source of moisture. It is not outside the realm of possibility that the vegetational and geographical characteristics of the Yeruu interact to produce a more stable supply of moisture through time for the eastern portion of the Mongolian Breadbasket.

\subsection{Implications for agriculture and water resources}

A key result from these reconstructions is that the western breadbasket region has experienced extended periods in the past that were much drier than the period of instrumental record. If we consider the present and future to be a part of a larger envelope of climatic variability better explained by the last 300 years of data than the last 50 , then it is possible that such dry periods may recur. What does this imply for agriculture and water resources development in Mongolia's future?

Water in Mongolia is highly limited but not completely scarce - per-capita renewable resources are about $13,000 \mathrm{~m}^{3} /$ year - and at first glance demand (about $0.5 \mathrm{~km}^{3}$ ) seems to be only a fraction of renewable supply (about $30-35 \mathrm{~km}^{3}$ of surface waters and $6-10 \mathrm{~km}^{3}$ of groundwater) (FAO, 2011; Regdel et al., 2012). However, this masks the spatial and temporal mismatches between water availability and demand that can be particularly acute for countries like Mongolia, where rain falls mainly in the summer and mainly in the north (Mun et al., 2008), and where infrastructure for water storage and diversion is low. In particular, it is not clear how a large decrease in precipitation would affect recharge rates for groundwater, which accounts for over $80 \%$ of total water withdrawals (FAO, 2011).

Agricultural withdrawals in the western breadbasket region are around $0.07 \mathrm{~km}^{3} /$ year, mostly for irrigation, falling third behind domestic $\left(0.12 \mathrm{~km}^{3} /\right.$ year $)$ and industrial $\left(0.265 \mathrm{~km}^{3} /\right.$ year $)$ withdrawals (Mun et al., 2008). As Mongolia moves its agricultural sector toward food self-sufficiency (Priess et al., 2011), withdrawals for irrigation will increase from current irrigation capacity of about 57,000 ha (Siebert et al., 2007) toward the country's full irrigation potential of about 518,000 ha (FAO, 2011). Model simulations suggest that irrigation supply in some upper reaches of tributaries in the western breadbasket region may fall short (Priess et al., 2011). This scenario would only be more likely under an extended dry regime, which has been more prevalent in the western breadbasket versus the eastern breadbasket region since the late-1700s. However, the more vulnerable segment of the agricultural sector may be pasture and livestock; a decrease in rainfall will decrease grass production, and any supplemental watering via groundwater will necessarily increase production costs for farmers. Regardless of the direction of future hydroclimate in Mongolia, additional water, such as that coming from irrigation, will be needed to meet future agricultural needs of undernourished areas like Mongolia with variable rainfall (Rockstrom et al., 2007).

The greatest need for caution in the face of reduced water availability may be in the industrial (and in particular, mining) sector. Beyond accounting for a huge portion of Mongolian water demand, the gold mining industry has significant detrimental effects on 
water quality, elevating turbidity and levels of suspended sediment and phosphorus (Stubblefield et al., 2005). While a decline in precipitation may mean less of the intense storm events that mobilize solid contaminants, it also means less dilution of the contaminants present. As the upstream steward of the Selenge's contribution to Lake Baikal, Mongolia holds a share of the responsibility in maintaining water quality in the tributary through a trans-boundary water agreement first signed in 1974 with the USSR, and updated in 1995 with the Russian Federation (Mun et al., 2008). The compounding effects of a weaker rainfall, expanded mining activity, and poor water treatment could potentially lead to conflict between the two states.

Finally, in regions with extreme climatic variation, like the western breadbasket, perhaps an incorporation of traditional land-use activities in Mongolia could ease socioeconomic struggles if the region swings from more persistent pluvial conditions to more persistent arid conditions. Nomadic pastoralism and sedentary agriculture complemented the other depending on climatic conditions (Lattimore, 1938), with nomadicism being better adapted for drought conditions and sedentary agriculture better adapted for more pluvial conditions. Of course, reaching greater agricultural independence using traditional methods for a population that has quadrupled since 1918 (National Statistics Office of Mongolia, 2012) might not be achievable. While the Virgin Lands program in Khazakstan, which includes irrigation, was an important adaptation for increasing agricultural productivity, it might not have long-term sustainability (Lioubimtseva and Henebry, 2009). But, perhaps some of the cultural wisdom regarding adaptation to environmental variability (e.g. Fernández-Giménez, 2000; Regdel et al., 2012), as has been done in a more drought-prone Tanzania (Mary and Majule, 2009), in combination with modern practices, as has been done in semi-arid Chile (Fiebig-Wittmaack et al., 2011), could be used to create an adaptive and productive agricultural sector in Mongolia.

\section{Conclusions}

Our reconstruction of Yeruu River streamflow (1680-2001) illustrates the historical extent of hydroclimatic variability in the Mongolian Breadbasket. Comparing the Yeruu reconstruction to the Selenge River streamflow (Davi et al., 2006), which encompasses the western part of the breadbasket region, we find that there are spatial differences in hydroclimatic variability, persistence, and trends. This spatial heterogeneity likely has important implications for managing water resources in this region that will become imperative to understand as agricultural and mining practices continue to rise. Both reconstructions show that the two halves of the Mongolian Breadbasket have experienced wet conditions during the 20th century relative to previous centuries, and that the recent, severe droughts in the early 21 st century are not unprecedented. Therefore, water resource managers must look beyond instrumental records to have an understanding of the potential variability in the natural climatic system. Future research should investigate the drivers behind spatial hydroclimatic patterns that we have identified within the Mongolian Breadbasket region.

\section{Acknowledgments}

We would like to thank Aria U., Bayarbaatar S., Byamba B., Chukkha D., Galabaatar B., and K. McGraw for assistance during fieldwork and Dr. G. Davaa for sharing updated streamflow data. This research was supported by the National Science Foundation DEB-0816700, ATM0117442 and OCE0402474. D. Martin-Benito acknowledges the financial support from the Spanish Ministry of Science and Innovation-Fulbright Postdoctoral fellowship. We thank two anonymous reviewers whose critiques improved the original manuscript. This is Lamont contribution 7567.

\section{Appendix A. Supplementary data}

Supplementary data associated with this article can be found, in the online version, at http://dx.doi.org/10.1016/j.agrformet. 2012.07.003.

\section{References}

Ahmed, M., Cook, E.R., 2011. Upper Indus River-flow Reconstruction Using Tree-Rings: Implications for Agriculture and Hydroelectricity., http://sites.nationalacademies.org/PGA/dsc/pakistan/PGA_053038.

Allen, C.D., Macalady, A.K., Chenchouni, H., Bachelet, D., McDowell, N., Vennetier, M., Kitzberger, T., Rigling, A., Breshears, D.D., Hogg, E.H., Gonzalez, P., Fensham, R. Zhang, Z., Castro, J., Demidova, N., Lim, J.H., Allard, G., Running, S.W., Semerci, A., Cobb, N., 2010. A global overview of drought and heat-induced tree mortality reveals emerging climate change risks for forests. Forest Ecol. Manage. 259, 660-684.

Angerer, J., Guodong, H., Fujisaki, I., Havstad, K., 2008. Climate change and ecosystems of Asia with emphasis on Inner Mongolia and Mongolia. Rangelands 30, 46-51.

Batima, P., Natsagdorj, L., Gombluudev, P., Erdenetsetseg, B., 2005. Observed climate change in Mongolia. In: Assessments and Adaptations to Climate Change (AIACC), pp. 1-26, www.aiaccproject.org.

Batisani, N., Yarnal, B., 2010. Rainfall variability and trends in semi-arid Botswana: implications for climate change adaptation policy. Appl. Geogr. 30, 483-489.

Bayar, S., 2008. General debate of the 63rd session of the United Nations general assembly. United Nations-Mongolia. http://www.un.int/mongolia/Archives/ 2008/Spch_63UNGA_PM_GenDeb_final_eng.htm (accessed 14.05.12).

Biondi, F., Kozubowski, T.J., Panorska, A.K., 2002. Stochastic modeling of regime shifts. Climate Res. 23, 23-30.

Biondi, F., Kozubowski, T.J., Panorska, A.K., 2005. A new model for quantifying climate episodes. Int. J. Climatol. 25, 1253-1264.

Breshears, D.D., Cobb, N.S., Rich, P.M., Price, K.P., Allen, C.D., Balis, R.G., Romme, W.H., Kastens, J.H., Floyd, M.L., Belnap, J., Anderson, J.J., Myers, O.B., Meyer, C.W., 2005. Regional vegetation die-off in response to global-change-type drought. Proc. Natl. Acad. Sci. U.S.A. 102, 15144-15148.

Cook, E., Bird, T., Peterson, M., Barbetti, M., Buckley, B., D’Arrigo, R., Francey, R. 1992. Climatic change over the last millennium in Tasmania reconstructed from tree-rings. Holocene 2, 205-217.

Cook, E.R., 1985. A Time Series Analysis Approach to Tree Ring Standardization. The University of Arizona.

Cook, E.R., Peters, K., 1981. The smoothing spline: a new approach to standardizing forest interior tree-ring width series for dendroclimatic studies. Tree Ring Bull. 41, 45-53.

Cook, E.R., Peters, K., 1997. Calculating unbiased tree-ring indices for the study of climatic and environmental change. Holocene 7, 361-370.

Cook, E.R., Krusic, P.J., 2011. Software. Tree Ring Laboratory of Lamont-Doherty Earth Observatory, http://www.Ideo.columbia.edu/treering-laboratory/resources/software (accessed 29.11.11).

Cook, E.R., Krusic, P.J., Jones, P.D., 2003. Dendroclimatic signals in long tree-ring chronologies from the Himalayas of Nepal. Int. J. Climatol. 23, 707-732.

Dahlin, B.H., 2002. Climate change and the end of the classic period in Yucutan: resolving a paradox. Anc. Mesoam. 13, 327-340.

Davi, N., Pederson, N., Leland, C., Nachin, B., Suran, B., Jacoby, G. Is eastern Mongolia drying? A long-term perspective of a multi-decadal trend. Water Resour. Res., under revision.

Davi, N., Jacoby, G., Fang, K., Li, J., D’Arrigo, R., Baatarbileg, N., Robinson, D., 2010. Reconstructing drought variability for Mongolia based on a large-scale tree ring network: 1520-1993. J. Geophys. Res. 115, 1-9.

Davi, N.K., Jacoby, G.C., Curtis, A.E., Baatarbileg, N., 2006. Extension of drought records for Central Asia using tree rings: West-Central Mongolia. J. Climate 19, 288-299.

Davi, N.K., Jacoby, G.C., D’Arrigo, R., Baatarbileg, N., Jinbao, L., Curtis, A.E., 2009. A treering-based drought index reconstruction for far-western Mongolia: 1565-2004. Int. J. Climatol. 29, 1508-1514.

Diffenbaugh, N.S., Hertel, T.W., Scherer, M., Verma, M., 2012. Response of corn markets to climate volatility under alternative energy futures. Nat. Climate Change $2,1-5$.

Dronin, N., Kirilenko, A., 2010. Climate change, food stress, and security in Russia. Reg. Environ. Change 11, 167-178.

Dugarjav, C., 2006. Mongolia in a market system. In: Statistical Yearbook of 1989-2002. National Statistics Office of Mongolia, Ulaanbaatar, 328 pp.

Dulamsuren, C., Hauck, M., Khishigjargal, M., Leuschner, H.H., Leuschner, C., 2010. Diverging climate trends in Mongolian taiga forests influence growth and regeneration of Larix sibirica. Oecologia 163, 1091-1102.

Dulamsuren, C., Hauck, M., Leuschner, H.H., Leuschner, C., 2011. Climate response of tree-ring width in Larix sibirica growing in the drought-stressed forest-steppe ecotone of northern Mongolia. Ann. Forest Sci. 68, 275-282. 
Enkh-Amgalan, S., Gunin, P.D., Drobyshev, Y.I., Basha, S.N., Amgalanbaatar, D., Baasandorzh, B., 2012. Modern use of pastures and watering security in the Middle Gobi aimak Mongolia (by example of Rashaant brigade). Arid Ecosyst. 2, 11-17.

FAO, 2011. Mongolia and FAO Achievements and success stories. Ulaanbaatar. Web document available: http://www.fao.org/fileadmin/templates/ rap/files/epublications/MongoliaedocFINAL.pdf.

Fernández-Giménez, M.E., 2000. The role of Mongolian nomadic pastoralists' ecological knowledge in rangeland management. Ecol. Appl. 10, 1318-1326.

Fiebig-Wittmaack, M., Astudillo, O., Wheaton, E., Wittrock, V., Perez, C., Ibacache, A., 2011. Climatic trends and impact of climate change on agriculture in an arid Andean valley. Clim. Change 111, 819-833.

Frank, D., Esper, J., Cook, E.R., 2006. On variance adjustments in tree-ring chronology development. TRACE 4, 56-66.

Friedman, J.H., 1984. A variable span smoother. Stanford, http://www.dtic.mil/cgibin/GetTRDoc?AD=ADA148241\&Location=U2\&doc=GetTRDoc.pdf.

Gray, S.T., Lukas, J.J., Woodhouse, C.A., 2011. Millennial-length records of streamflow from three major upper Colorado River Tributaries. JAWRA: J. Am. Water Resour. Assoc. 47, 702-712.

Gregory, P.J., Ingram, J.S.I., Brklacich, M., 2005. Climate change and food security. Philos. Trans. R. Soc. Lond. B: Biol. Sci. 360, 2139-2148.

Grumm, R., 2011. The central European and Russian heat event of July-August 2010 Bull. Am. Meteorol. Soc. 92, 1285-1296.

Holmes, R.L., 1983. Computer-assisted quality control in tree-ring dating and measurement. Tree-Ring Bull. 43, 69-78.

Hornbeck, R., Keskin, P., 2011. The Evolving Impact of the Ogallala Aquifer: Agricultural Adaptation to Groundwater and Climate.

Huckaby, L.S., Kaufmann, M.R., Fornwalt, P.J., Stoker, J.M., Dennis, C., 2003. Field guide to old ponderosa pines in the Colorado Front Range. Nat. Resour. Res., 43.

Humphrey, C., Sneath, D., 1999. The End of Nomadism? Society, State, and the Environment in Inner Asia. Duke University Press, Durham, NC.

Lafon, C.W., Speer, J.H., 2002. Using dendrochronology to identify major ice storm events in oak forests of southwestern Virginia. Climate Res. 20, 41-54.

Lattimore, O., 1938. The geographical factor in Mongol history. Geogr. J. 91, 1-16.

Leland, C., Pederson, N., Hessl, A.E., Davi, N.K., Nachin, B. A hydroclimatic regionalization of north-central Mongolia as inferred from tree rings. Dendrochronologia, in review.

Leland, C.W., 2011. Hydroclimatic Variability in North-central Mongolia as Inferred from Tree Rings. West Virginia University, $84 \mathrm{pp}$.

Lioubimtseva, E., Henebry, G.M., 2009. Climate and environmental change in arid Central Asia: impacts, vulnerability, and adaptations. J. Arid Environ. 73, 963-977.

Lobell, D.B., Schlenker, W., Costa-Roberts, J., 2011. Climate trends and global crop production since 1980. Science (New York, NY), 616.

Lorimer, C.G., Frelich, L.E., 1989. A methodology for estimating canopy disturbance frequency and intensity in dense temperate forests. Can. J. Forest Res. $19,651-663$

Lucero, L.J., 2002. The collapse of the classic Maya: a case for the role of water control. Am. Anthropol. 104, 814-826.

Marin, A., 2010. Riders under storms: contributions of nomadic herders' observations to analysing climate change in Mongolia. Global Environ. Change 20, $162-176$.

Mary, A.L., Majule, A.E., 2009. Impacts of climate change, variability and adaptation strategies on agriculture in semi arid areas of Tanzania: the case of Manyoni District in Singida Region, Tanzania. Afr. J. Environ. Sci. Technol. 3, 206-218.

Meko, D., 1997. Dendroclimatic reconstruction with time varying predictor subsets of tree indices. J. Climate 10, 687-696.

Meko, D.M., Stahle, D.W., Griffin, D., Knight, T.A., 2011. Inferring precipitationanomaly gradients from tree rings. Quaternary Int. 235, 89-100.

Mitchell, T.D., Jones, P.D., 2005. An improved method of constructing a database of monthly climate observations and associated high-resolution grids. Int. J. Climatol. 25, 693-712.

Mun, Y., Ko, H., Janchivdorj, L., Gomboev, B., Kang, S.I., Lee, C.H., 2008. Integrated Water Management Model on the Selenge River Basin: Status Survey and Investigation (Phase I), Seoul, Korea.
National Statistics Office of Mongolia, 2012. Mongolia National Census 2010 Provision Results, http://www.toollogo2010.mn/doc/Main results_20110615_to EZBH_for print.pdf (accessed 14.05.12).

Orkhonselenge, A., Krivonogov, S.K., Mino, K., Kashiwaya, K., Safonova, I.Y. Yamamoto, M., Kashima, K., Nakamura, T., Kim, J.Y., 2012. Holocene sedimentary records from Lake Borsog, eastern shore of Lake Khuvsgul, Mongolia, and their paleoenvironmental implications. Quaternary Int., 1-15.

Pederson, N., Jacoby, G.C., D’Arrigo, R., Cook, E.R., Buckley, B.M., Dugarjav, C., Mijiddorj, R., 2001. Hydrometeorological reconstructions for Northeastern Mongolia derived from tree rings: 1651-1995. J. Climate 14, 872-881.

Pederson, N., Tackett, K., McEwan, R.W., Clark, S., Cooper, A., Brosi, G., Eaton, R. Stockwell, R.D. Prospects for reconstructing drought using non-classical treering data: drought as an important factor of tree growth. Can. J. Forest Res. under revision.

Piao, S., Ciasis, P., Huang, Y., Shen, Z., Peng, S., Li, J., Zhou, L., Liu, H., Ma, Y., Ding, Y., Friedlingstein, P., Liu, C., Tan, K., Yu, Y., Zhang, T., Fang, J., 2010. The impacts of climate change on water resources and agriculture in China. Nature 467, 43-51.

Priess, J.A., Schweitzer, C., Wimmer, F., Batkhishig, O., Mimler, M., 2011. The consequences of land-use change and water demands in Central Mongolia. Land Use Policy 28, 4-10.

Regdel, D., Dugarzhav, C., Gunin, P.D., 2012. Ecological demands on socioeconomic development of Mongolia under climate aridization. Arid Ecosyst. 2, 1-10.

Rockstrom, J., Lannerstad, M., Falkenmark, M., 2007. Assessing the water challenge of a new green revolution in developing countries. Proc. Natl. Acad. Sci. U.S.A. $104,6253-6260$.

Sato, T., Kimura, F., Kitoh, A., 2004. Cloud frequency in eastern Mongolia and its relation to orography. In: Proceedings of the Third International Workshop on Terrestrial Change in Mongolia, Ulan Bator, Ulaanbaatar, pp. 107-109.

Sato, T., Kimura, F., Kitoh, A., 2007. Projection of global warming onto regiona precipitation over Mongolia using a regional climate mode. J. Hydrol. 333 144-154.

Siebert, S., Doll, P., Feick, S., Hoogeveen, Frenken, K., 2007. Global Map of Irrigation Areas Version 4.0.1, http://www.fao.org/nr/water/aquastat/ irrigationmap/index10.stm (accessed 14.05.12).

Siurua, H., Swift, J., 2002. Drought and zud but no famine (yet) in the Mongolian herding economy. IDS Bull. 33, 88-97.

Stokes, M.A., Smiley, S.T.L., 1968. An Introduction to Tree-Ring Dating. University of Chicago Press, Chicago.

Stubblefield, A., Chandra, S., Eagen, S., Tuvshinjargal, D., Davaadorzh, G., Gilroy, D. Sampson, J., Thorne, J., Allen, B., Hogan, Z., 2005. Impacts of gold mining and land use alterations on the water quality of central Mongolian rivers. Integr. Environ. Assess. Manage. 1, 365-373, http://www.ncbi.nlm.nih.gov/pubmed/16639903.

Swetnam, T.W., Brown, T.M., 1992. Oldest known conifers in the southwestern United States: temporal and spatial patterns of maximum age. In: Kaufman, M.R., Moir, W.H., Bassett, R.L. (Eds.), Old Growth Forests in the Southwest and Rocky Mountain Regions. USDA Forest Service General Technical Report RM213. USDA Forest Service Rocky Mountain Forest and Range Experiment Station, Fort Collins, CO, pp. 24-38, http://www.ltrr.arizona.edu/ tswetnam/twspdf/oldgrow.pdf (accessed 31.12.11).

Ummenhofer, C.C., D’Arrigo, R.D., Anchukaitis, K.J., Buckely, B.M., Cook, E.R. Links between Indo-Pacific climate variability and drought in the monsoon Asia drought atlas. Climate Dyn., accepted.

Urban, D., Roberts, M.J., Schlenker, W., Lobell, D.B., 2012. Projected temperature changes indicate significant increase in interannual variability of U.S. maize yields. Clim. Change 112, 525-533.

Vinod, H.D., 2006. Maximum entropy ensembles for time series inference in economics. J. Asian Econ. 17, 955-978.

Voropay, N.N., Maksyutova, E.V., Balybina, A.S., 2011. Contemporary climatic changes in the Predbaikalie region. Environ. Res. Lett. 6, 045209.

Wegren, S.K., 2011. Food security and Russia's 2010 drought. Eurasian Geogr. Econ. $52,140-156$.

Wigley, T., Briffa, K., Jones, P., 1984. On the average value of correlated time series, with applications in dendroclimatology and hydrometeorology. J. Climate Appl. Meteorol. 23, 201-213. 


\section{Supplemental Tables}

Table s1. Kolmogorov-Smirnov test comparing density distributions - p-values are listed; significant $(p<0.05)$ values are in bold

Yeruu reconstruction:

\begin{tabular}{|c|c|c|c|c|c|c|}
\hline & $1700-1749$ & 1750-1799 & $1800-1849$ & $1850-1899$ & $1900-1949$ & $1950-1997$ \\
\hline $1700-1749$ & -- & & & & & \\
\hline $1750-1799$ & 0.396 & -- & & & & \\
\hline $1800-1849$ & 0.272 & 0.869 & -- & & & \\
\hline $1850-1899$ & 0.179 & 0.869 & 0.864 & -- & & \\
\hline 1900-1949 & 0.272 & 0.967 & 0.869 & 0.964 & -- & \\
\hline 1950-1997 & 0.085 & 0.916 & 0.638 & 0.959 & 0.615 & -- \\
\hline
\end{tabular}

Selenge reconstruction (from Davi et al. 2006):

\begin{tabular}{c|c|c|c|c|c|c}
\hline & $1700-1749$ & $1750-1799$ & $1800-1849$ & $1850-1899$ & $1900-1949$ & $1950-1997$ \\
\hline $1700-1749$ & -- & & & & & \\
$1750-1799$ & $\mathbf{0 . 0 0 1}$ & -- & & & & \\
$1800-1849$ & 0.393 & $\mathbf{0 . 0 0 0}$ & -- & & & \\
$1850-1899$ & 0.549 & $\mathbf{0 . 0 0 0}$ & 0.544 & -- & & \\
$1900-1949$ & 0.272 & $\mathbf{0 . 0 2 2}$ & $\mathbf{0 . 0 1 2}$ & 0.112 & -- & \\
$1950-1997$ & $\mathbf{0 . 0 0 0}$ & 0.302 & $\mathbf{0 . 0 0 0}$ & $\mathbf{0 . 0 0 0}$ & 0.076 & -- \\
\hline
\end{tabular}


Table s2. Descriptive Statistics for Yeruu (top) and Selenge (bottom) reconstructions Yeruu:

\begin{tabular}{c|c|c|c|c|c}
\hline & Mean & Median & SD & Skewness & Kurtosis \\
\hline $1700-1749$ & 77.76 & 77.39 & 40.54 & -0.14 & 2.65 \\
$1750-1799$ & 92.56 & 93.36 & 36.72 & -0.10 & 2.43 \\
$1800-1849$ & 88.68 & 90.55 & 39.24 & -0.22 & 2.23 \\
$1850-1899$ & 93.68 & 95.00 & 35.23 & -0.17 & 2.77 \\
$1900-1949$ & 90.68 & 88.77 & 33.35 & -0.22 & 2.53 \\
$1950-1997$ & 94.88 & 98.11 & 36.92 & -0.43 & 2.57 \\
\hline Full Period & $\mathbf{8 9 . 6 7}$ & $\mathbf{9 1 . 7 2}$ & $\mathbf{3 7 . 2 1}$ & $\mathbf{- 0 . 2 5}$ & $\mathbf{2 . 5 9}$ \\
\hline
\end{tabular}

Selenge (from Davi et al., 2008):

\begin{tabular}{l|c|c|c|c|c}
\hline & Mean & Median & SD & Skewness & Kurtosis \\
\hline $1700-1749$ & 187.21 & 179.13 & 50.99 & 0.36 & 2.34 \\
$1750-1799$ & 227.17 & 230.43 & 72.18 & -0.28 & 2.21 \\
$1800-1849$ & 174.97 & 164.23 & 47.16 & 0.86 & 3.22 \\
$1850-1899$ & 175.91 & 174.27 & 51.73 & 0.18 & 2.06 \\
$1900-1949$ & 200.95 & 201.27 & 62.79 & 0.21 & 2.58 \\
$1950-1997$ & 222.55 & 221.90 & 53.64 & -0.34 & 2.73 \\
\hline Full Period & $\mathbf{1 9 7 . 9 4}$ & $\mathbf{1 9 6 . 3 6}$ & $\mathbf{6 0 . 3 0}$ & $\mathbf{0 . 2 7}$ & $\mathbf{2 . 3 9}$ \\
\hline
\end{tabular}




\section{Supplemental Figures}
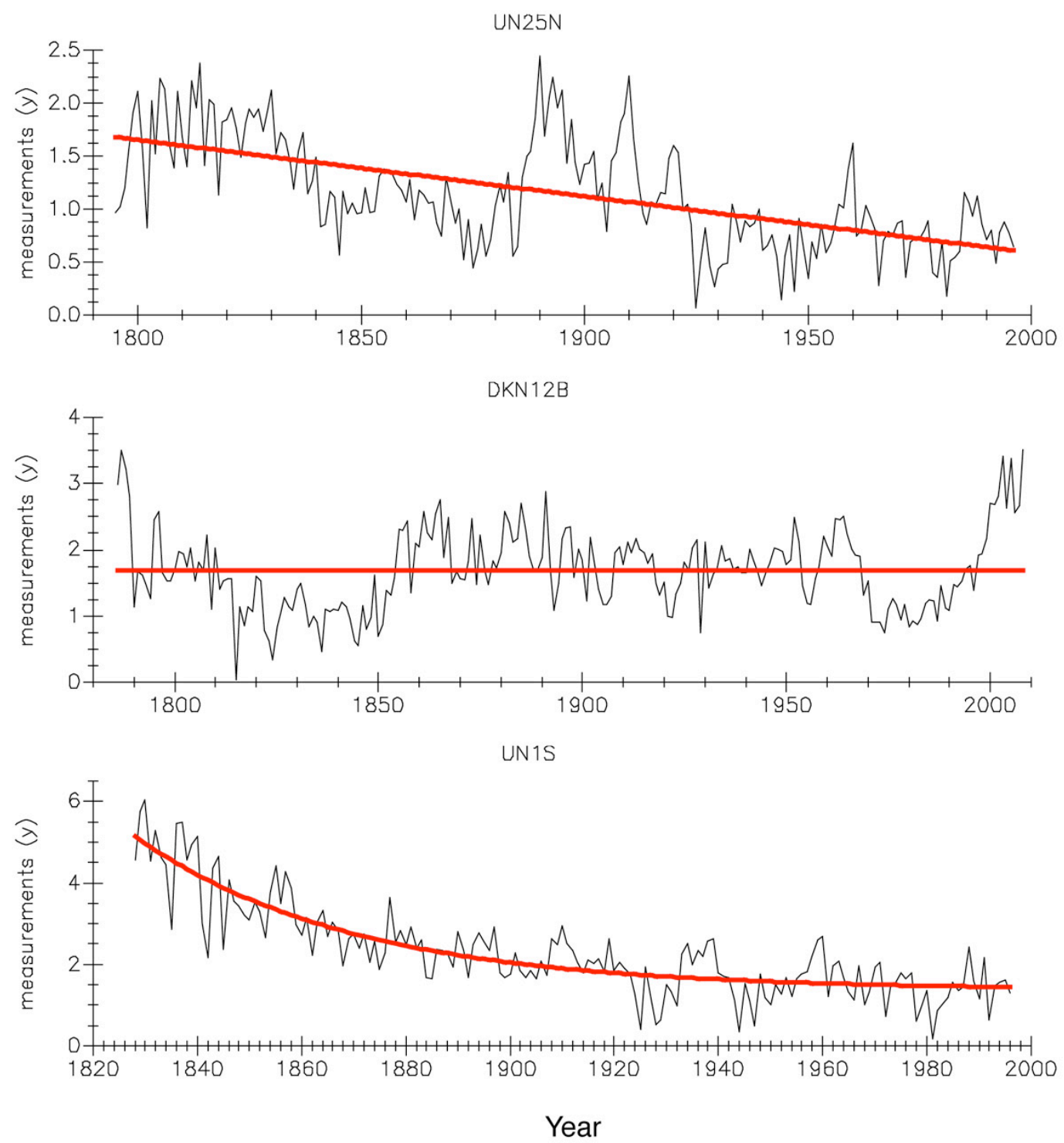

Fig. s1 - Examples of ring-width series from 'classic' drought sensitive sites that were detrended to remove potential disturbances or non-climatic changes in growth (top two panels) versus the more common negative exponential decline in ring widths from these sites (bottom panel). Abrupt increases in ring width that resemble a reduction in tree-to-tree competition can be seen in ca 1888 in UN25N (top panel) and ca 1855 and 1998 in DKN12B (middle panel). The abrupt declines not seen in all of the trees and might be related to significant damage related to ice, snow, or wind damage can be seen in ca 1923 in UN25N (top panel) and ca 1959 in DKN12B (middle panel). Note: a significant drought occurred in Mongolia in the 1920s, which complicates the drop in UN25N. This series drops suddenly and does not approach radial increment similar to earlier increments until the late-1950s, which is well after the 1920s drought ended. Units are $\mathrm{mm}$. 

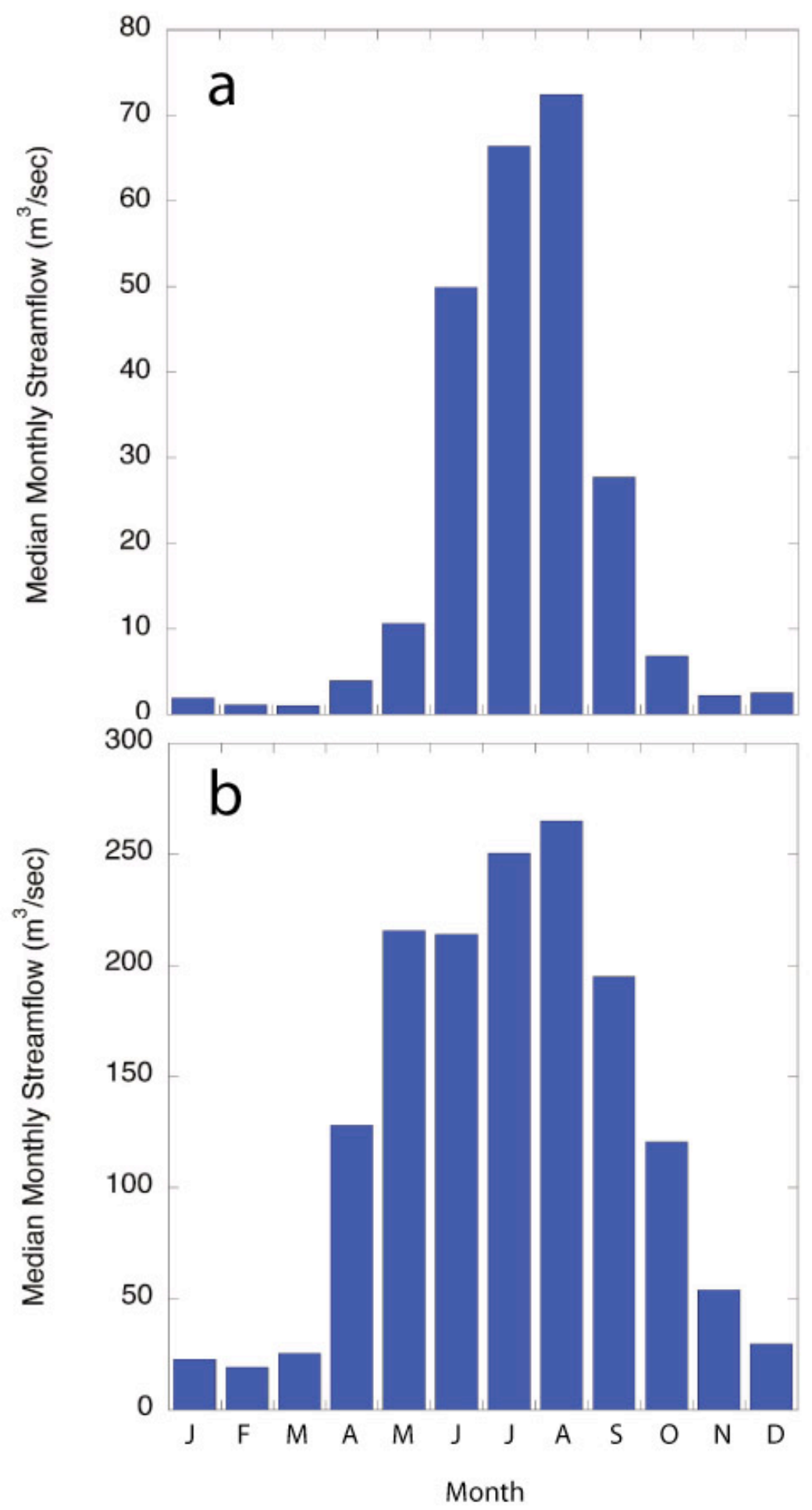

Fig. s2 -Median monthly streamflow for a) Yeruu River and b) Selenge River. 

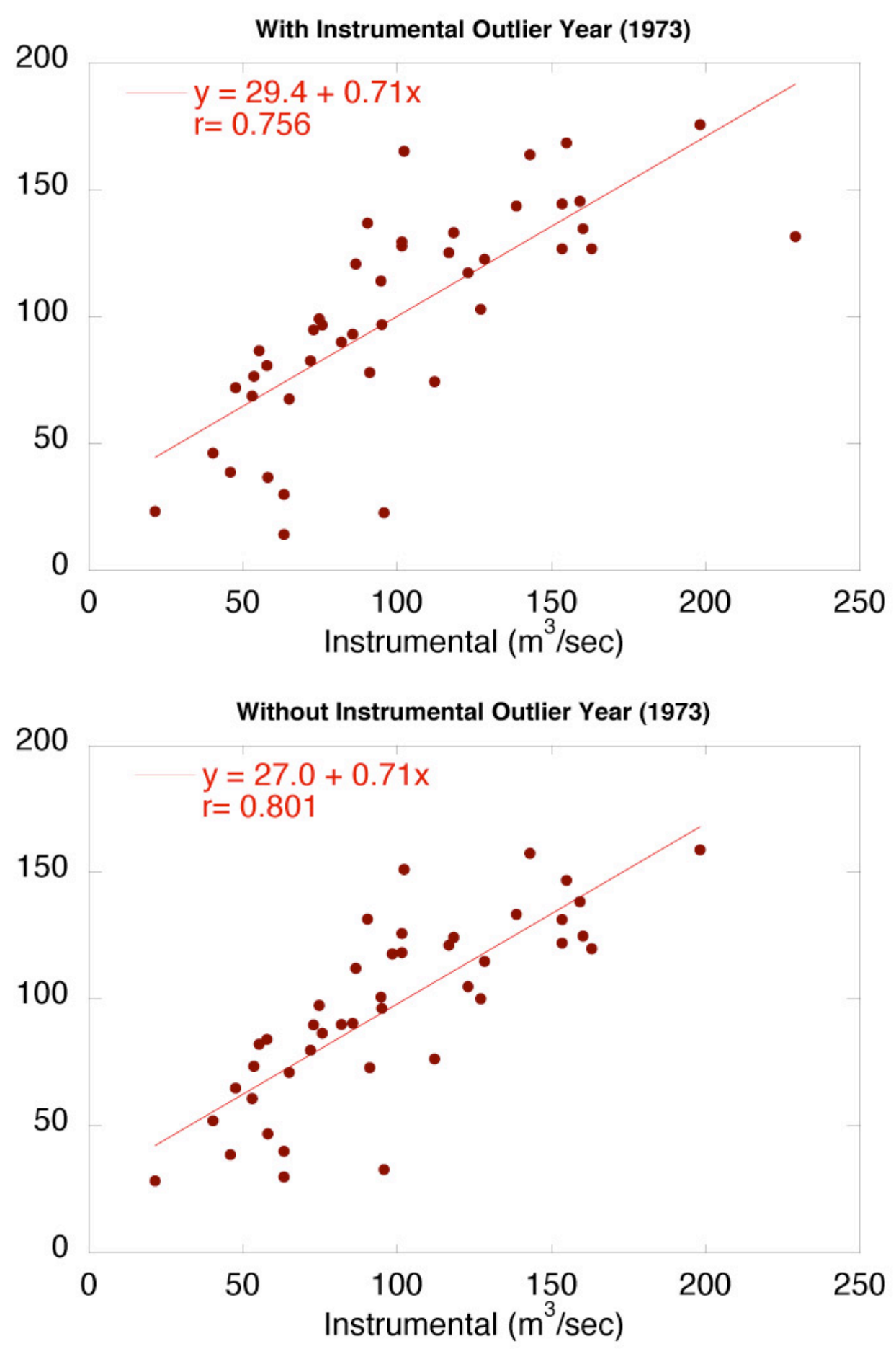

Fig. s3 - Scatter plots between the instrumental measurements and tree-ring based reconstruction of the Yeruu River (a) with and (b) without the 1973 outlier instrumental measurement. 

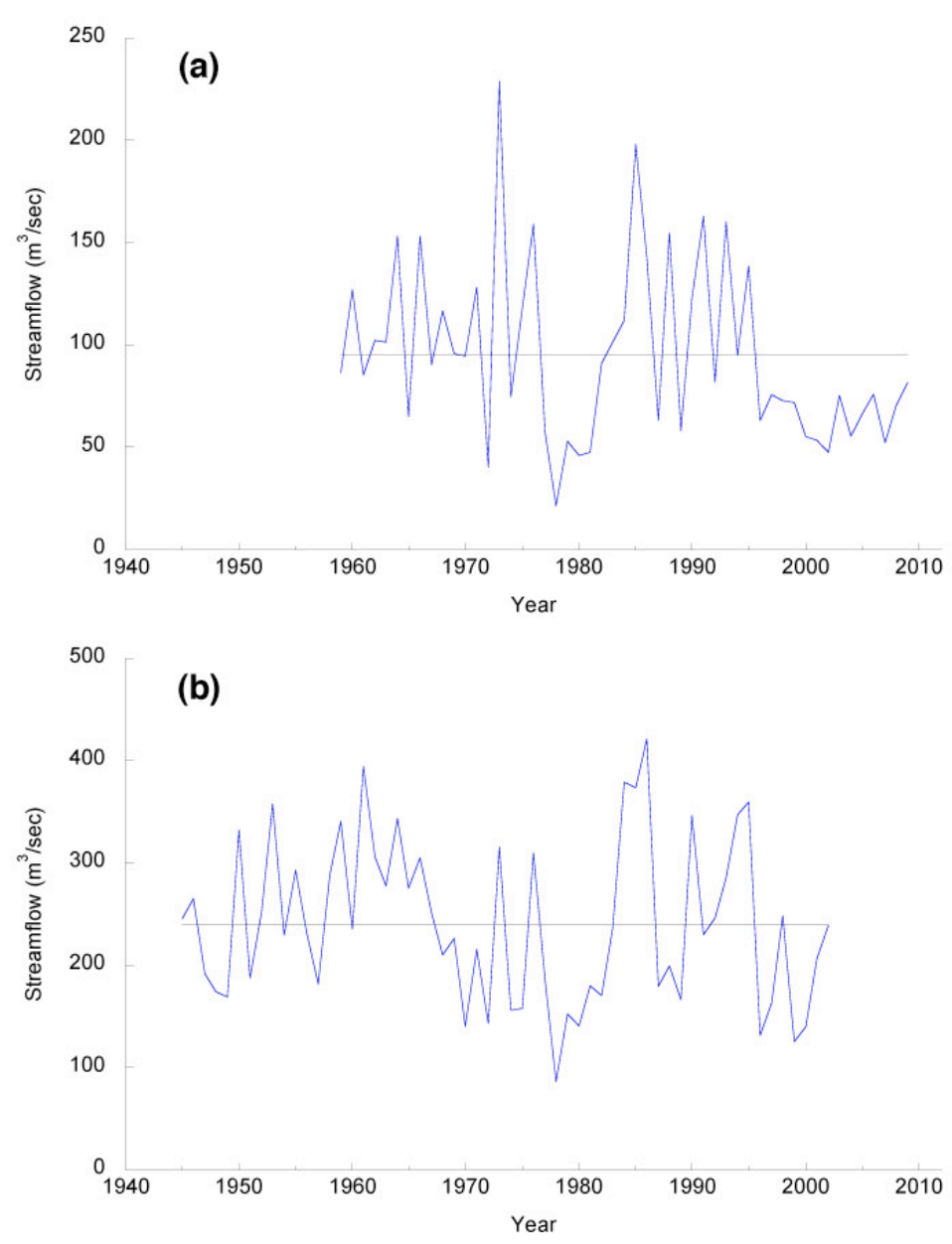

Fig. s4 - Average instrumental May-September streamflow for the (a) Yeruu (1959-2009) and (b) Selenge (1945-2002) Rivers. 


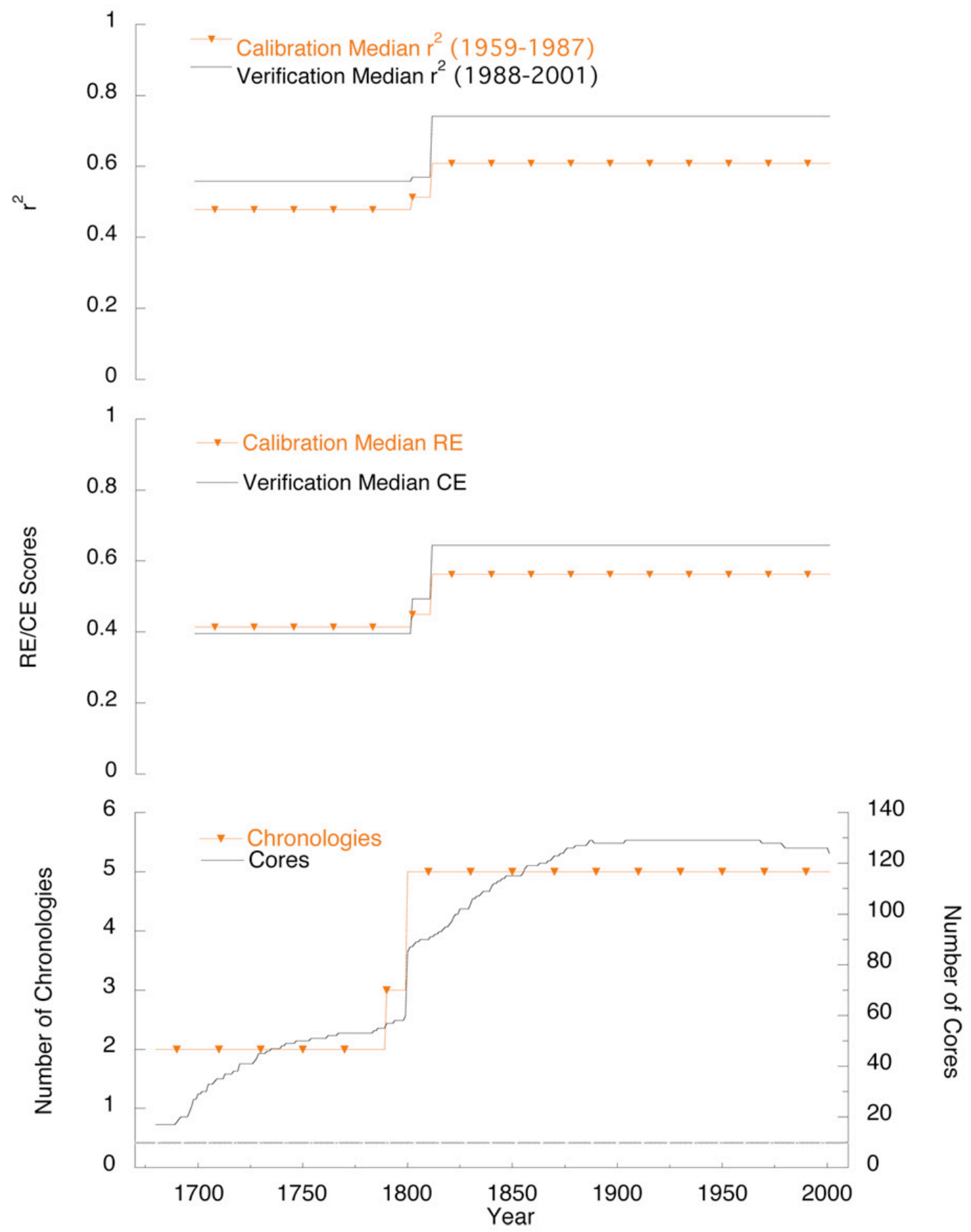

Fig. s5 - Calibration-verification statistics and chronology and core replication through time. Top panel: Median calibration (line with inverted triangles) and verification $r^{2}$. Middle panel: Median calibration RE (line with inverted triangles) and verification CE. Bottom panel: Chronology (line with inverted triangles) and core replication. The grey dashed line in the bottom panel indicates the presence of 10 cores. Core replication is above 10 cores for the entire reconstruction. 


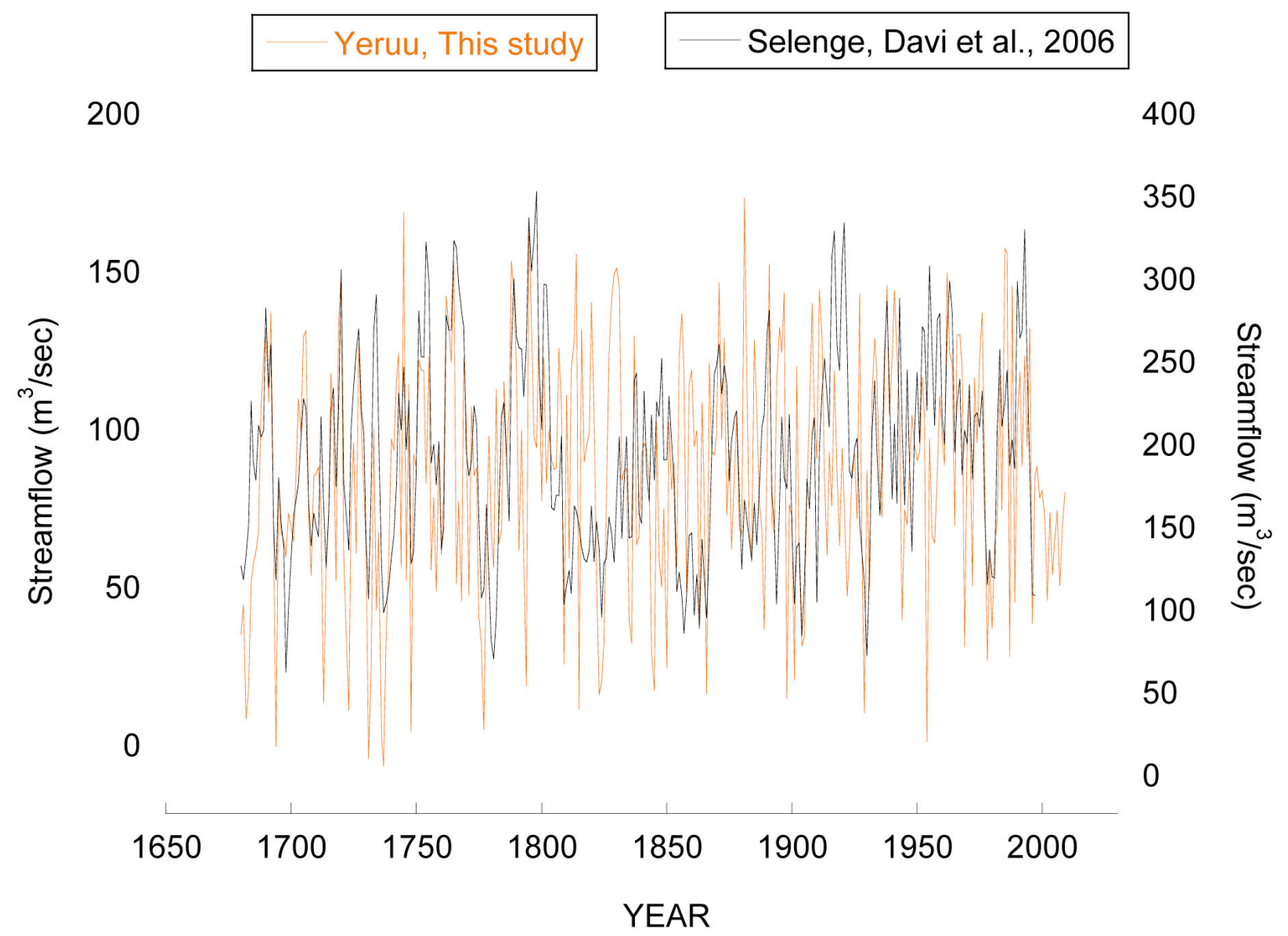

Fig. s6 - Comparison of annual reconstructions of the Yeruu River (this study, orange line) and the Selenge River (Davi et al., 2006; black line). The two records correlate at $0.397(p<0.001)$ from 1680-1997. Note: $y$-axis scales differ because each river has a different mean flow. 

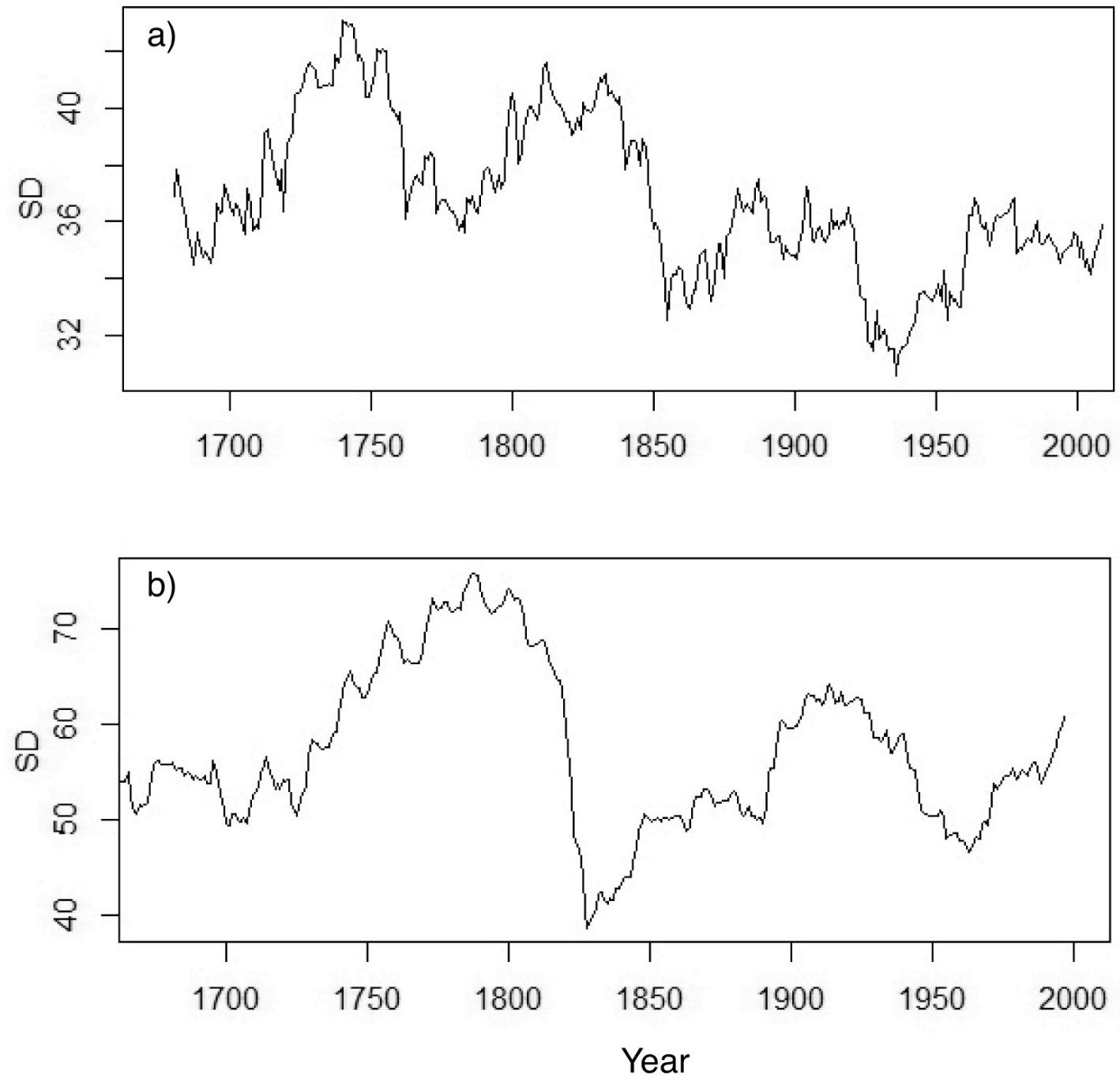

Fig. s7 - Running 50-year window of standard deviation for the a) Yeruu River reconstruction and b) Selenge River reconstruction. 

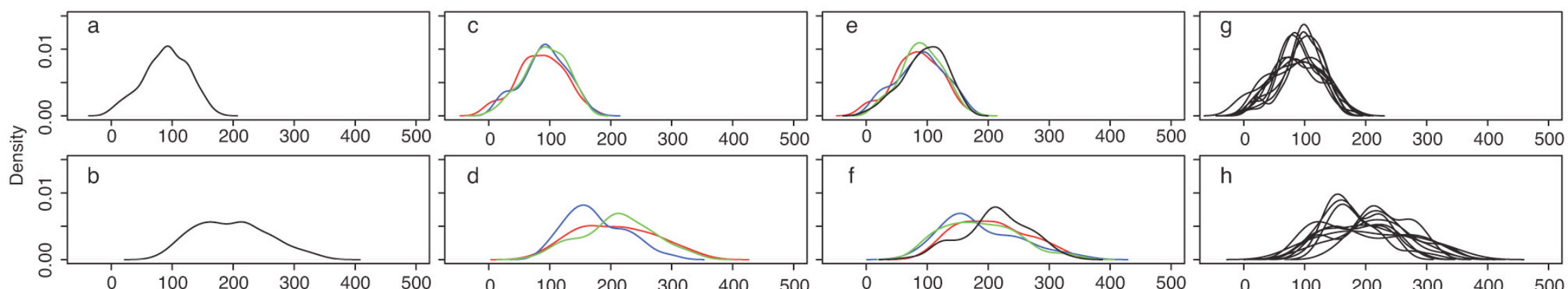

Streamflow $\left(\mathrm{m}^{3} / \mathrm{sec}\right)$

Fig. s8 - Probability density plots (PDF) for varying time periods. From top to bottom moving left to right: a) Yeruu River - 17001997; b) Selenge River - 1700-1997; c) Yeruu River - 100-year periods; d) Selenge River - 100-year periods; e) Yeruu River - 75-year periods; f) Selenge River - 75-year periods; g) Yeruu River - 30-year periods; h) Selenge River - 30-year periods. Color-coding for the 100 years plots (c, d) are 1700-1799 (red); 1800-1899 (blue); 1900-1997 (green). For the 75 years plots (e, f) the color codes are: 1700-1774 (red); 1775-1849 (blue); 1850-1924 (green); 1925-1997 (black). Color-coding was not performed for the 30-year plots (g, h) as 1) it would clutter the image, and 2) we were less interested in the density structure for specific 30-year intervals than in investigating whether the Yeruu reconstruction $(\mathrm{g})$ would display more of a bi-modal structure similar to the Selenge reconstruction $(d, f, h)$. While more of the expected bi-modality is seen in the 30-year interval PDFs of the Yeruu reconstruction, it does not have the range of disparate distributions as seen in the Selenge reconstruction. 

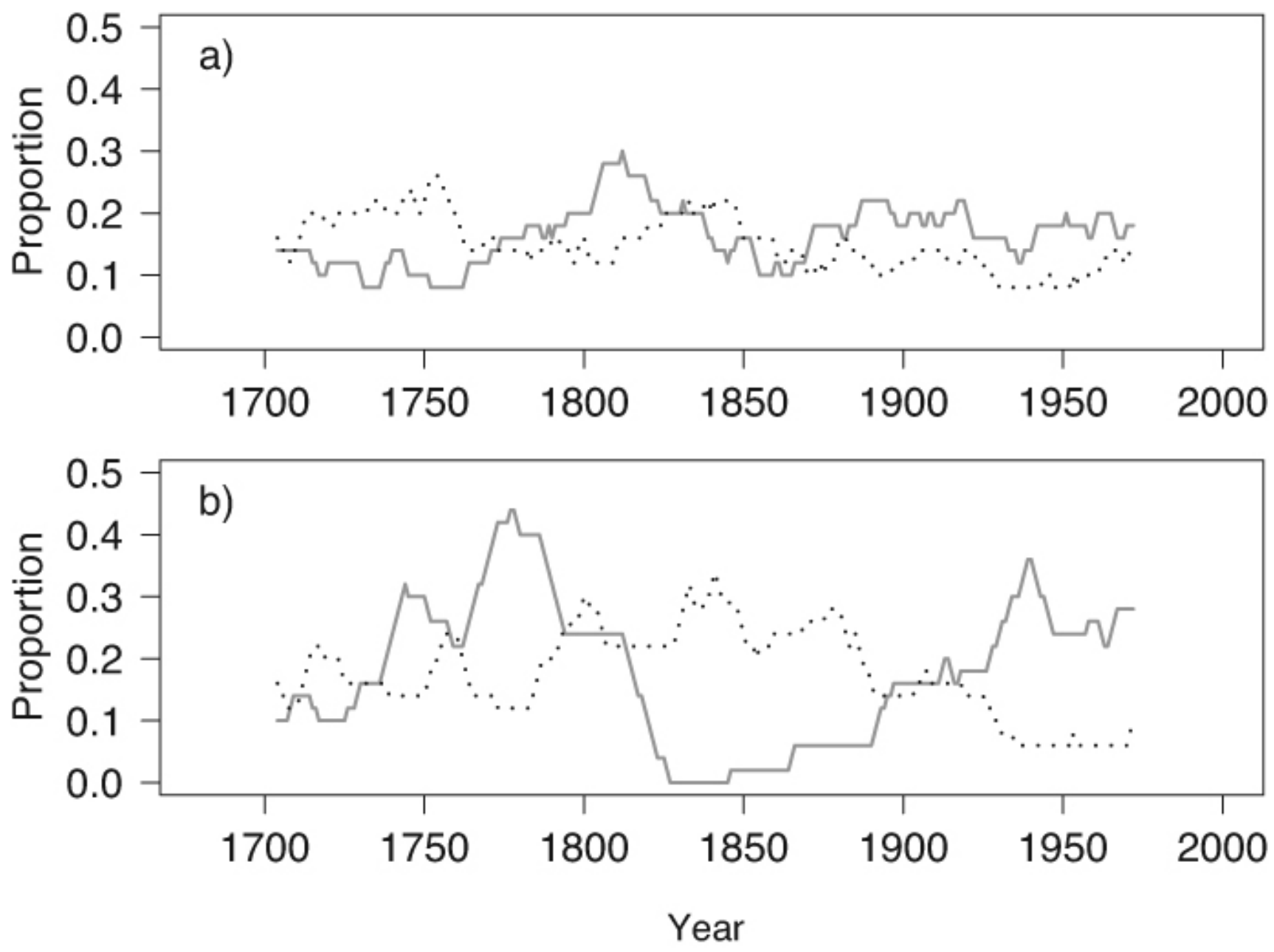

Fig. s9 - 50-year moving window of the proportion of drought (dotted) and pluvial (solid) years in the Yeruu (a) and Selenge (b) reconstructions. Droughts were defined as $<1$ SD below the mean and pluvials were defined as $>1$ SD above the mean. 

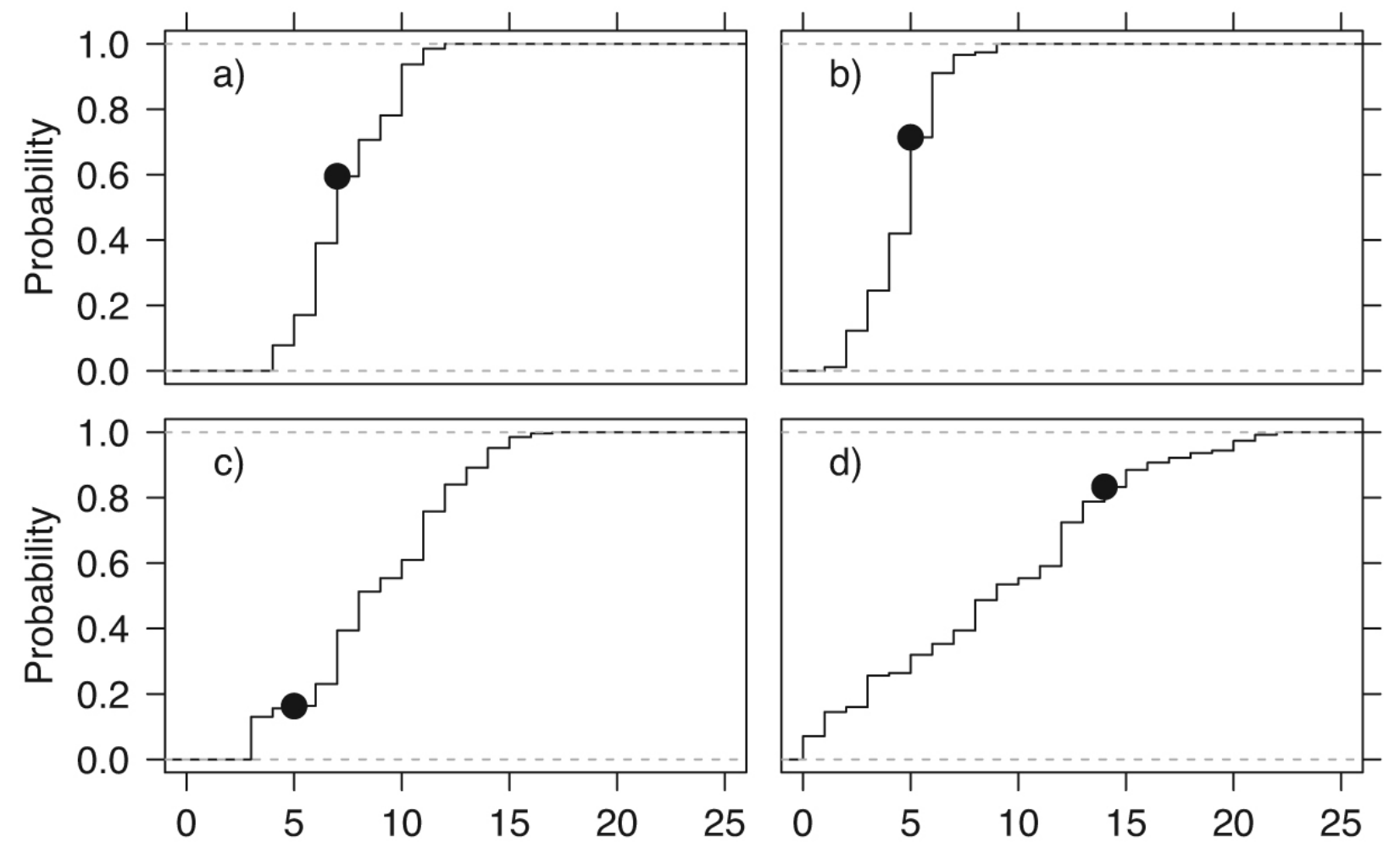

Number of Years

Number of Years

Fig. s10 - Empirical Cumulative Distribution Function (ECDF) of the number of drought (<1 SD below the mean) and pluvial ( $>1$ SD above the mean) years for a 50-year moving window. Top graphs are based on the Yeruu streamflow reconstruction for dry (a) and wet (b) years, whereas the bottom graphs are from the Selenge streamflow reconstruction for dry (c) and wet (d) years. The black circle represents the last common 50-year window (1948-1997) within the distribution. 